
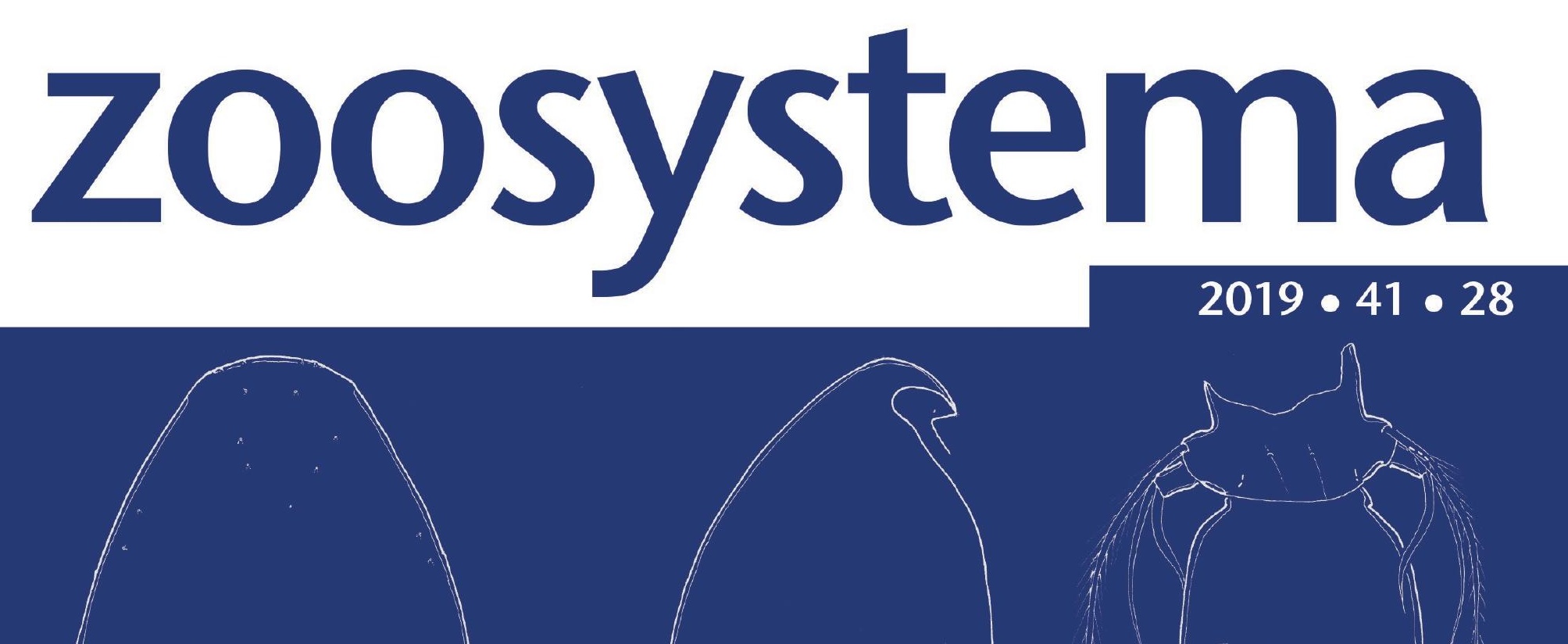

Two new species of the similis-subgroup of Triconid Böttger-Schnack, 1999 (Copepoda, Oncaeidae) and a redescription of T. denticula Wi, Shin \& Soh, 2011 from the northeastern equatorial Pacific
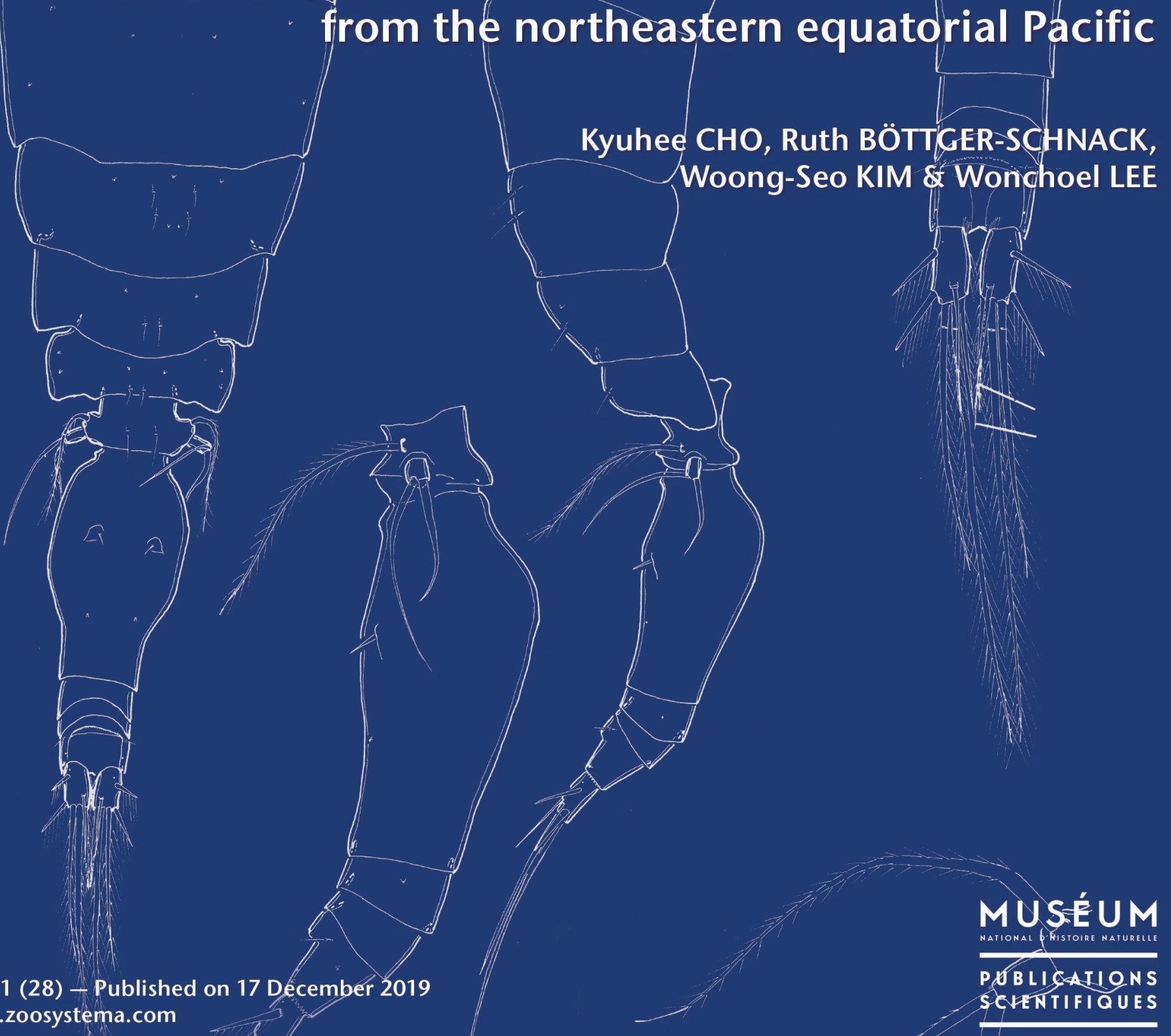
DiRECTEUR DE LA PUBLICATION: Bruno David

Président du Muséum national d'Histoire naturelle

\section{RÉDACTRICE EN CHEF / EDITOR-IN-CHIEF: Laure Desutter-Grandcolas}

ASSISTANTS DE RÉDACTION / ASSISTANT EDITORS: Anne Mabille (zoosyst@mnhn.fr), Emmanuel Côtez

\section{Mise en PAge / PAge LAYOUt: Anne Mabille}

COMITÉ SCIENTIFIQUE / SCIENTIFIC BOARD:

James Carpenter (AMNH, New York, États-Unis)

Maria Marta Cigliano (Museo de La Plata, La Plata, Argentine)

Henrik Enghoff (NHMD, Copenhague, Danemark)

Rafael Marquez (CSIC, Madrid, Espagne)

Peter Ng (University of Singapore)

Norman I. Platnick (AMNH, New York, États-Unis)

Jean-Yves Rasplus (INRA, Montferrier-sur-Lez, France)

Jean-François Silvain (IRD, Gif-sur-Yvette, France)

Wanda M. Weiner (Polish Academy of Sciences, Cracovie, Pologne)

John Wenzel (The Ohio State University, Columbus, États-Unis)

COUVERTURE / COVER:

Triconia komo n. sp. female.

Zoosystema est indexé dans / Zoosystema is indexed in:

- Science Citation Index Expanded (SciSearch ${ }^{\circledR}$ )

- ISI Alerting Services ${ }^{\circledR}$

- Current Contents ${ }^{\circledR} /$ Agriculture, Biology, and Environmental Sciences ${ }^{\circledR}$

- Scopus ${ }^{\circledR}$

Zoosystema est distribué en version électronique par / Zoosystema is distributed electronically by:

- BioOne ${ }^{\circledR}$ (http://www.bioone.org)

Les articles ainsi que les nouveautés nomenclaturales publiés dans Zoosystema sont référencés par / Articles and nomenclatural novelties published in Zoosystema are referenced by:

- ZooBank ${ }^{\circledR}$ (http://zoobank.org)

Zoosystema est une revue en flux continu publiée par les Publications scientifiques du Muséum, Paris / Zoosystema is a fast track journal published by the Museum Science Press, Paris

Les Publications scientifiques du Muséum publient aussi / The Museum Science Press also publish:

Adansonia, Geodiversitas, Anthropozoologica, European Journal of Taxonomy, Naturae, Cryptogamie sous-sections Algologie, Bryologie, Mycologie.

Diffusion - Publications scientifiques Muséum national d'Histoire naturelle

CP $41-57$ rue Cuvier F-75231 Paris cedex 05 (France)

Tél. : 33 (0)1 40794805 / Fax: 33 (0)1 40793840

diff.pub@mnhn.fr / http://sciencepress.mnhn.fr

(C) Publications scientifiques du Muséum national d'Histoire naturelle, Paris, 2019

ISSN (imprimé / print): 1280-9551/ ISSN (électronique / electronic): 1638-9387 


\title{
Two new species of the similis-subgroup of Triconia Böttger- Schnack, 1999 (Copepoda, Oncaeidae) and a redescription of T. denticula Wi, Shin \& Soh, 2011 from the northeastern equatorial Pacific
}

\author{
Kyuhee $\mathrm{CHO}$ \\ Envient inc., 602, 74, Jeonmin-ro, Yuseong-gu, 34052 Daejeon (Korea) \\ and Marine Ecosystem Research Center, \\ Korea Institute of Ocean Science \& Technology (KIOST), \\ and 385, Haeyang-ro, Yeongdo-gu, 49111 Busan (Korea) \\ and Department of Life Science, Hanyang University, 04763 Seoul (Korea) \\ hee3592@hanmail.net \\ Ruth BÖTTGER-SCHNACK \\ GEOMAR Helmholtz-Centre for Ocean Research Kiel, Kiel (Germany) \\ rboettgerschnack@geomar.de \\ Woong-Seo KIM \\ The President, Korea Institute of Ocean Science \& Technology (KIOST), \\ 385, Haeyang-ro, Yeongdo-gu, 49111 Busan (Korea) \\ wskim@kiost.ac.kr \\ Wonchoel LEE \\ Department of Life Science, Hanyang University, 04763 Seoul (Korea) \\ wlee@hanyang.ac.kr
}

Cho K., Böttger-Schnack R., Kim W.-S. \& Lee W. 2019. - Two new species of the similis-subgroup of Triconia BöttgerSchnack, 1999 (Copepoda, Oncaeidae) and a redescription of $T$. denticula Wi, Shin \& Soh, 2011 from the northeastern equatorial Pacific. Zoosystema 41 (28): 567-593. https://doi.org/10.5252/zoosystema2019v41a28. http://zoosystema. com/41/28

\section{ABSTRACT}

Three species of the similis-subgroup of the genus Triconia Böttger-Schnack, 1999 in the family Oncaeidae Giesbrecht, 1893 ["1892"] are described based on specimens collected by using a fine mesh net in the northeastern equatorial Pacific Ocean. One species is newly recorded in the equatorial Pacific, and the other two species are new to science. Triconia komo n. sp. is closely related to T. hawii (Böttger-Schnack \& Boxshall, 1990), but differs distinctly in the relative length of the outer basal seta on P5 in the female as well as slightly in the relative length of the seta VI on caudal ramus in both sexes. Triconia onnuri $\mathrm{n}$. sp. closely resembles T. similis (Sars, 1918), but females can be distinguished by the relative length of the outer exopodal seta and the outer basal seta on P5. Both sexes differ from T. similis in the relative lengths of endopodal spines on swimming legs 3 and 4 as well as in the form of caudal seta VI. The female of Triconia denticula Wi, Shin \& Soh, 2011, which is newly recorded in the equatorial Pacific, is redescribed including morphological details and differences compared to the original description from Korean waters. The type material of $T$. denticula deposited in the National Institute of Biological Resources, Incheon (NIBR) was re-examined and found to be inconclusive for 


KEY WORDS
Tropical Pacific,
zooplankton,
Oncaeidae,
new species.

MOTS CLÉS

Pacifique tropical,

zooplancton, espèces nouvelles. taxonomic purposes because the deposited copepod material and its labelling does not correspond to the description of the species. A fundamental revision of the type material of $T$. denticula is required. The present account includes an indication of the intraspecific variation in the endopodal spine lengths on swimming legs 2 to 4 for all three species, which is essential for assessing the usefulness of these characters for unequivocal identification of Triconia species. The spine lengths on exopodal segments 1 and 2 on swimming legs 3 and 4 are proposed as new morphometric characters for the identification of males of Triconia species, which are otherwise very similar in morphology.

\section{RÉSUMÉ}

Deux nouvelles espèces du sous-groupe similis du genre Triconia Böttger-Schnack, 1999 (Copepoda, Oncaeidae) et redescription de T. denticula Wi, Shin \& Soh, 2011 du nord est du Pacifique équatorial. Trois espèces du sous-groupe similis du genre Triconia Böttger-Schnack, 1999 (Famille des Oncaeidae Giesbrecht, 1893 [“1892”]) sont décrites à partir de spécimens collectés avec un filet à mailles fines dans le nord est du Pacifique équatorial. L'une est nouvellement signalée du Pacifique équatorial, et les deux autres sont nouvelles pour la science. Triconia komo n. sp. est étoitement apparentée à T. hawii (Böttger-Schnack \& Boxshall, 1990), mais en diffère nettement par la longueur relative de la soie basale externe sur $\mathrm{P} 5$ chez la femelle et à un moindre degré par la longueur relative de la soie VI sur le ramus caudal chez les deux sexes. Triconia onnuri n. sp. ressemble fortement à T. similis (Sars, 1918), mais les femelles sont reconnaissables à la longueur relative de la soie exopodale externe et de la soie basale externe sur P5. Les deux sexes diffèrent de T. similis par les longueurs relatives des épines endopodales sur les pattes natatoires 3 et 4 ainsi que par la forme de la soie caudale VI. La femelle de Triconia denticula Wi, Shin \& Soh, 2011, espèce nouvellement signalée du Pacifique équatorial, est redécrite notamment par des détails morphologiques et des différences par rapport à la description originale sur des spécimens originaires des eaux coréennes. Le matériel type de T. denticula déposé au National Institute of Biological Resources, Incheon (NIBR) a été rééxaminé : le matériel de copépodes déposé et les étiquettes ne correspondent pas à la description de l'espèce, ce qui est problématique pour des recherches en taxonomie. Le matériel type de T. denticulata devra être sérieusement révisé. Ici, nous rendons compte de la variation intraspécifique pour la longueur des épines endopodales sur les pattes natatoires 2 à 4 chez les trois espèces, étape cruciale pour juger de l'utilité de ces caractères pour identifier sans ambiguïté les espèces de Triconia. Nous proposons que la longueur des épines sur les segments exopodaux 1 et 2 des pattes natatoires 3 et 4 soit considérée comme de nouveaux caractères morphométriques pour l'identification des mâles des espèces de Triconia, dont la morphologie est à part cela très semblable.

\section{INTRODUCTION}

The genus Triconia was established by Böttger-Schnack (1999) transferring 14 species of the paraphyletic genus Oncaea Philippi, 1843 (Böttger-Schnack \& Huys 1998) to a new genus on account of the conical process on the distal margin of the third segment of the endopod of swimming leg 4. Within the genus three subgroups had been distinguished, characterized by the presence of a dorso-posterior projection on the P2-bearing somite (the conifera-subgroup), and the presence (the similis-subgroup) or absence (the dentipes-subgroup) of integumental pockets on the anterior surface of the labrum (Böttger-Schnack 1999).

In addition to the 14 species known at that time, BöttgerSchnack (1999) described five new species from the Red Sea in the same account: three species of the similis-subgroup (T. recta Böttger-Schnack, 1999, T. gonopleura Böttger-Schnack, 1999, and T. parasimilis Böttger-Schnack, 1999) and two species of the dentipes-subgroup (T. elongata Böttger-Schnack, 1999 and T. giesbrechti Böttger-Schnack, 1999), respectively. Since then several new species of Triconia have been described from different areas of the world ocean by Heron \& Frost (2000), Wi et al. (2010, 2011, 2012) and Cho et al. (2013). Currently there are 26 valid species in the genus Triconia (Walter \& Boxshall 2018), (conifera-subgroup: 13 species, similis-subgroup: eight species, dentipes-subgroup: five species). The distinctiveness of the three subgroups is supported by molecular genetic studies (Böttger-Schnack \& Machida 2011), but species of the similis-subgroup do not appear to be genetically homogeneous. In subsequent morphometric re-examinations, two different groups were suggested by the authors, which differ in the proportional spine lengths on the endopod of swimming leg 2 . In the 1 st group (including T. similis (Sars, 1918), T. hawii (Böttger-Schnack \& Boxshall, 1990), T. recta and T. denticula Wi, Shin \& Soh, 2011), the distal spine clearly exceeds the distal conical process, while in the 2 nd group (including T. minuta (Giesbrecht, 1893 ["1892"], T. umerus (Böttger-Schnack \& Boxshall, 1990), T. gonopleura, and T. parasimilis), the distal spine extends only to the tip of the cone. However, the proposed morphometric differentiation of the two groups has not yet been substantiated by more extended studies on the intraspecific variability of 


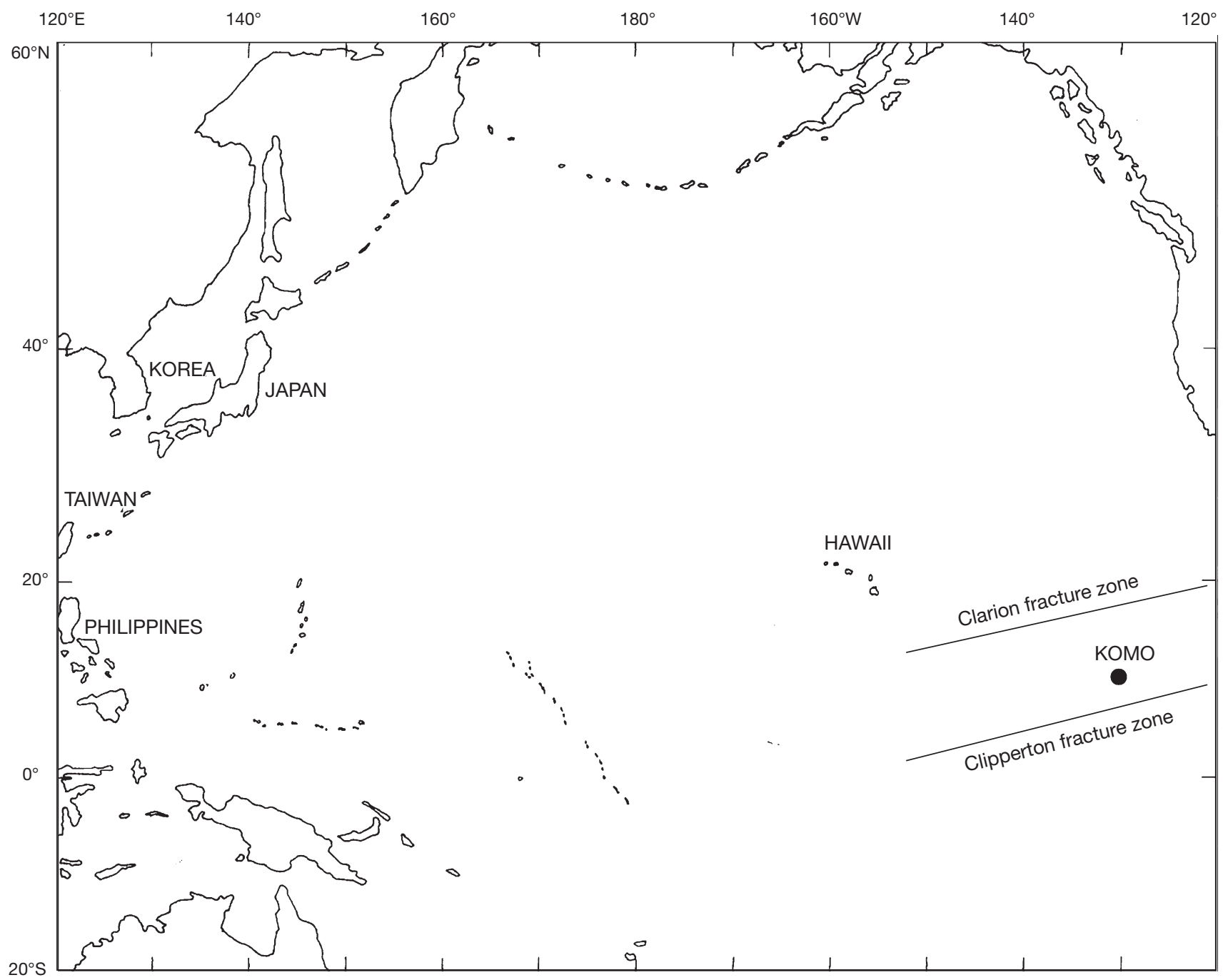

FIG. 1. - Location of sampling station (KOMO, KODOS Long-term Monitoring Station) in the northeastern equatorial Pacific Ocean.

the spine lengths, and the molecular genetic analyses, which seem to support this subgrouping, so far included only two species of the 2 nd group and one species of the 1 st group (Böttger-Schnack \& Machida 2011). Thus, further verification is required. In the present paper, the splitting of the similis-subgroup is accepted for practical purposes and species belonging to the 1 st group are described. Triconia species of the 2 nd group from the equatorial Pacific Ocean have been described in a separate paper (Cho et al. 2017a).

During a survey of the zooplankton community carried out as part of an environmental monitoring program established for the Korean manganese nodules mining site in the northeastern equatorial Pacific Ocean (MOMAF 2009), a morphological taxonomic study of oncaeid copepods from the upper $100 \mathrm{~m}$ was conducted (Cho 2011). By using a fine-mesh net of $60 \mu \mathrm{m}$ mesh size, many small species of the family were sampled, including three species of the Triconia similis-subgroup: T. denticula, which was originally described from the Korean waters, is newly recorded in the equatorial Pacific Ocean, and the other two species are new to science.
The present paper provides a detailed description of both sexes of the new species and a redescription of female $T$. denticula including morphological details not noted in the original description from the Korean waters. An indication of the variation in endopodal spine lengths on swimming legs 2 to 4 is provided for each species, which is essential for assessing the usefulness of these characters for unequivocal species identification (cf. Cho et al. 2013, 2017b). An overview of morphological characteristics separating the six species of the similis-subgroup of Triconia in the world ocean is given.

\section{MATERIAL AND METHODS}

The copepods were collected in the northeastern Pacific Ocean $\left(10^{\circ} 30^{\prime} \mathrm{N}, 131^{\circ} 20^{\prime} \mathrm{W}\right.$, Station KOMO [KODOS Long-term Monitoring Station] located in the KODOS [Korea Deep Ocean Study] area) on 21 August 2009 (Fig. 1). Vertical hauls were taken from $100 \mathrm{~m}$ depth to the surface using a conical net $(60 \mathrm{~cm}$ mouth diameter) with a fine mesh size of $60 \mu \mathrm{m}$. The specimens 
were initially preserved in $99.9 \%$ ethyl alcohol on board. For morphological examination, the copepods were sorted out from the zooplankton samples under a stereomicroscope (Zeiss Semi 2000-C) in the laboratory. Each specimen was dissected with tungsten needles and mounted in lactophenol, and sealed with transparent nail-varnish. All drawings were prepared using a drawing tube attached to an Olympus BX51 or Leica DM2500 differential interference contrast microscope. Some appendages and the genital apertures of two females (Triconia komo n. sp. and T. onnuri n. sp.) were examined with a scanning electron microscope (JEOL JSM-6390LV). The specimens fixed with $99.9 \%$ ethyl alcohol were immersed in $100 \%$ isoamyl acetate. After the final step, specimens were dried by the critical-point method using liquid carbon dioxide. Dried specimens were mounted on stubs and coated with gold using an ion sputter.

The type material of $T$. denticula from the Korean waters, collected in the East China Sea (south of Cheju Island, $32^{\circ} 00^{\prime} \mathrm{N}$, $126^{\circ} 5^{\prime} \mathrm{E}$ on 27 June 2009) was loaned from the collections of the National Institute of Biological Resources (NIBR), Incheon (registration number NIBRIV0000214676-78) for comparison with the specimens from the equatorial Pacific Ocean. Upon re-examination of the copepod material it was found to be insufficient for taxonomic purpose, due to poor conditions of the slides, erroneous labelling and inclusion of other species under the name Triconia denticula (for details cf. "Remarks" of $T$. denticula).

Total body length and the ratio of prosome to urosome including caudal rami were measured laterally or sometimes dorsally from the anterior margin of the prosome to the posterior margin of the caudal rami, not considering the various degrees of telescoping of somites. The length to width ratio of the caudal rami was calculated from measuring the length along the inner margin in dorsal view and the width at the insertion point of lateral seta II. The relative lengths of spines on the distal endopod segments of P2-P4 were computed in relation to the length of the distal spine; the position of the tips of the distal and outer distal endopodal spines is described relative to the tip of the distal conical process. Scale bars in the figures are indicated in micrometers $(\mu \mathrm{m})$.

The descriptive terminology is adapted from Huys et al. (1996). Pores and other integumental structures (e.g., pits, scales) on the body surface were figured or mentioned only when discernible under a light microscope.

In this study, the family Oncaeidae Giesbrecht, 1893 ["1892"] is placed in the order Cyclopoida Burmeister, 1834 following Boxshall \& Halsey (2004), although this taxonomic assignment is not universally accepted (Ho et al. 2006). In a recent study investigating the molecular phylogenetic relationships between all 10 copepod orders, the Poecilostomatoida Thorell, 1859, lies as cyclopoid-poecilostome lineage within the order Cyclopoida (Khodami et al. 2017), and most families formerly included in Poecilostomatoida are now included in the suborder Ergasilida Khodami, Mercado-Salas, Tang \& Martinez Arbizu, 2019 (Khodami et al. 2019).

The family Oncaeidae was established by Wilhelm Giesbrecht in his comprehensive monograph on the pelagic copepods of the Gulf of Naples (Giesbrecht 1893 [“1892”]). Following the arguments given by Holthuis \& Vervoort (2006), the actual date of publication of Giesbrecht's monograph appears to be different (1893) from the date specified in the work (1892). According to Article 22A.2.3. of the International Code of Zoological Nomenclature, it is recommended to cite both dates with the actual date cited first, followed by the imprint date for information and enclosed in parentheses or other brackets and quotation marks.

All specimens on slides were deposited in National Institute of Biological Resources (NIBR), Incheon and additional materials were stored at Muséum national d'Histoire naturelle, (MNHN), Paris.

\author{
ABBREVIATIONS \\ Abbreviations used in the text and figures \\ $\mathrm{Al}$ antennule; \\ A2 antenna; \\ ae aesthetasc; \\ P1-P6 first to sixth thoracopod; \\ exp exopod; \\ enp endopod; \\ exp (enp)-1 $(2,3)$ to denote the proximal (middle, distal) segment \\ of a three-segmented ramus.
}

$\begin{array}{ll}\text { Abbreviations } & \text { used in Tables } \\ \text { AS } & \text { anal somite; } \\ \text { BS } & \text { outer basal seta; } \\ \text { CR } & \text { caudal ramus; } \\ \text { DS } & \text { distal spine; } \\ \text { IS } & \text { inner exopodal spine; } \\ \text { L } & \text { length; } \\ \text { ODS } & \text { outer distal spine; } \\ \text { OS } & \text { outer exopodal spine; } \\ \text { OSDS } & \text { outer subdistal spine; } \\ \text { Pro } & \text { prosome; } \\ \text { Uro } & \text { urosome; } \\ \text { W } & \text { width. }\end{array}$

Roman numerals indicate spines;

Arabic numerals indicate setae.

\section{SYSTEMATICS}

\section{Family ONCAEIDAE Giesbrecht, 1893 [“1892”] \\ Genus Triconia Böttger-Schnack, 1999}

Triconia komo n. sp.

(Figs 2-5; 13A; Tables 2-4)

urn:Isid:zoobank.org:act:CA4A0457-8738-4141-BE3C-1A3F55CBD619

TYPE LOCALITY. - Northeastern equatorial Pacific Ocean $\left(10^{\circ} 30^{\prime} \mathrm{N}\right.$, $\left.131^{\circ} 20^{\prime} \mathrm{W}, 0-100 \mathrm{~m}\right)$.

TYPE MATERIAL. - Holotype. 1 \%; NIBRIV0000838000; 10³0’N, $131^{\circ} 20^{\prime} \mathrm{W} ; 0-100 \mathrm{~m}$; dissected and mounted on 10 slides, collected from the type locality on 21.VIII.2009 by D. J. Ham.

Paratypes. 5 \% ; NIBRIV0000838001-005; $10^{\circ} 30^{\prime} \mathrm{N}, 131^{\circ} 20^{\prime} \mathrm{W}$; each dissected and mounted on each of 5,8 or 10 slides (lost a slide of urosome with P5 of the third paratype). - $20^{7}$; NIBRIV0000838006-007; each dissected and mounted on 8 or 9 slides, respectively. - 4 \%, $10^{7} \mathrm{kept}$ in one vial in alcohol, MNHNIU-2019-2282. All specimens are from the type locality. 


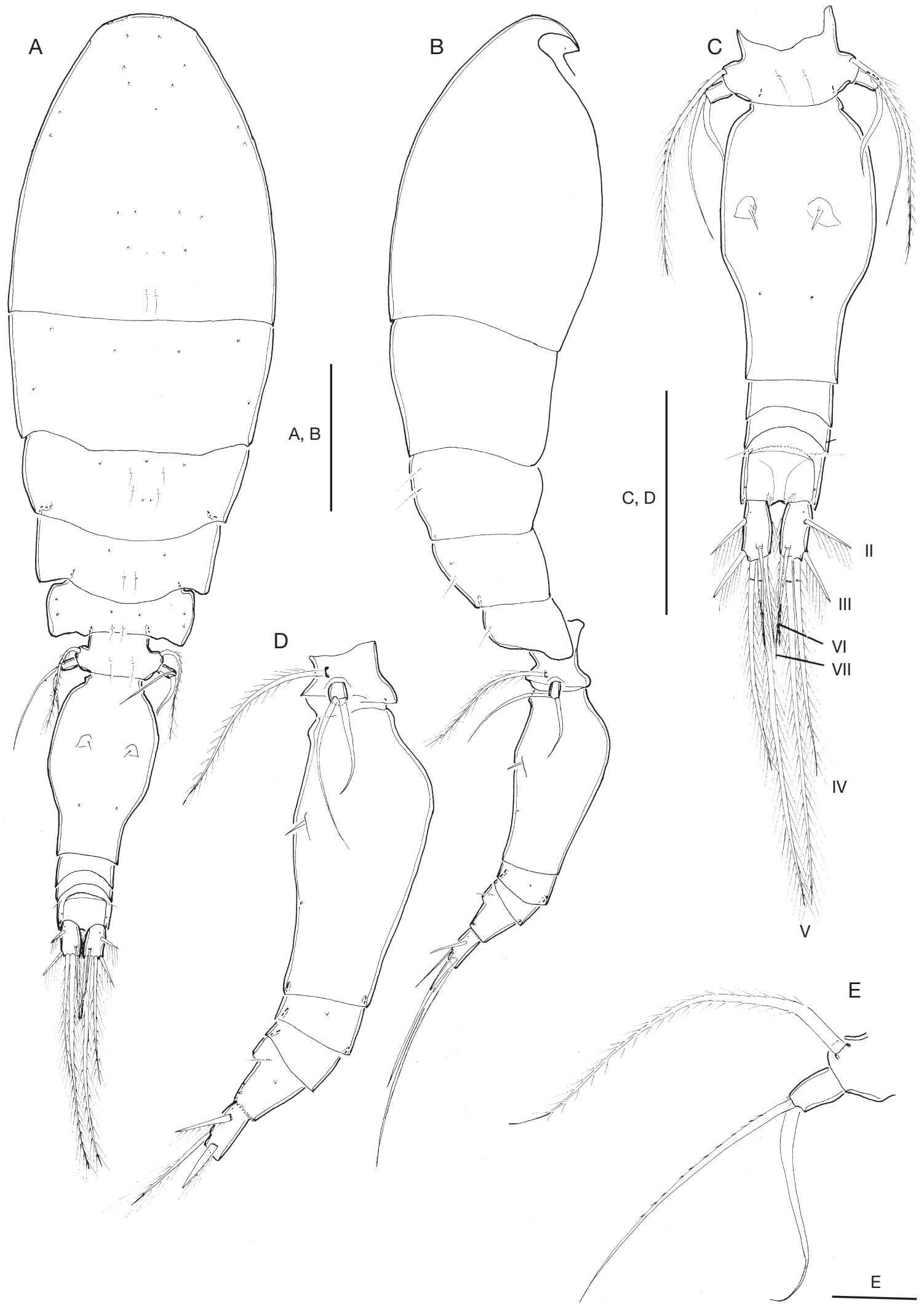

FIG. 2. - Triconia komo n. sp. female: A, habitus, dorsal; B, habitus, lateral; C, urosome, dorsal, with setae on caudal rami numbered using Roman numerals; D, urosome, lateral; E, P5, dorsal view. Abbreviations: see Material and methods. Scale bars: A-D, $100 \mu \mathrm{m} ; \mathrm{E}, 20 \mu \mathrm{m}$. 
ETYMOLOGY. - The species is named after the station name KOMO [KODOS (the Korea Deep Ocean Study) Long-term Monitoring Station' in the Korean mining area for manganese nodules in the central part of the Clarion-Clipperton Fracture Zone], which is the type locality of the new species in the northeastern equatorial Pacific Ocean.

\section{DESCRIPTION}

Female

Body length. 613-658 $\mu \mathrm{m}$, based on six specimens.

Exoskeleton weakly chitinized. Prosome 2.0 times length of urosome, excluding caudal rami, 1.8 times urosome length including caudal rami. P2-bearing somite without conspicuous dorsoposterior projection in lateral aspect (Fig. 2B). Integumental pores as figured in Fig. 2A, B. Pleural areas of $\mathrm{P} 4$-bearing somite with rounded posterolateral corners in lateral aspect. One pair of secretory pores laterally discernible on first postgenital somite (Fig. 2D).

Genital double-somite. 1.7 times as long as maximum width (measured in dorsal aspect) and about 2.1 times as long as postgenital somites combined; bottle-shaped with largest width measured at anterior two thirds and with moderately rounded lateral margins, posterior part tapering gradually. Paired genital apertures located at about $2 / 5$ distance from anterior margin of genital double-somite; armature represented by 1 long spine and two minute spinous processes (Fig. 13A). Pore pattern on dorsal surface as in Fig. 2C.

Anal somite. Slightly wider than long; slightly longer than caudal rami (Fig. 2C). Secretory pore discernible on either side of anal opening and additional pair of pores anterolaterally on anal somite. Anterior margin of anal opening with transverse row of minute denticles. Posterior margin of somite finely serrate ventrally and laterally (Fig. 2D).

Caudal ramus (Fig. 2C). 1.8 times longer than wide. Dorsal seta (VII) about half the length of seta IV, about as long as seta VI. Inner margin of somite with few long, fine spinules. Dorsal anterior surface (Fig. 2C) with secretory pore near insertion of seta II.

Antennule (Fig. 3A). 6-segmented. Armature formula: 1-[3], 2-[8], 3-[5], 4-[3+ae], 5-[2+ae], 6-[6+(1+ae)].

Antenna (Fig. 3B). 3-segmented, distinctly reflexed. Coxobasis armed with bipinnate seta at inner distal corner; surface of coxobasis with row of long, fine spinules along outer and inner margins and with few minute denticles along outer margin. Endopod segments unequal in length; proximal endopod segment subtriangular forming outer lobate outgrowth bearing spinular patch, with row of denticles along posterior inner margin. Distal endopod segment distinctly shorter than proximal endopod segment and articulating with narrow cylindrical base; with two patches of short spinules along outer margin; lateral armature consisting of one pinnate seta (III) and three naked setae (I, II, IV), seta II + III longest; distal armature consisting of one long curved seta (E), four curved setae (A-D) of graduated length, ornamented with pinnules along entire inner margin $(A)$ or at middle part $(B, C)$, and two slender bare setae (F and $G$ ), seta $G$ shorter than seta $D$ and slightly shorter than $\mathrm{F}$.

Labrum (Fig. 3G, H). Distinctly bilobed. Each lobe with row of minute denticles around outer ventral margin and strong dentiform processes converging and slightly decreasing in size medially (arrowed in Fig. 3H). Lobes separated by medial concavity covered anteriorly by single hyaline lamella (Fig. 3G). Posterior part of medial concavity ornamented with four long sclerotized, dentiform processes ("teeth”), posterior surface with group of three secretory pores located on proximal part of each lobe (Fig. 3H). Anterior surface (Fig. 3G) with paired row of long setules either side of median swelling, and paired integumental pockets latero-posteriorly, which are difficult to illustrate under a light microscope because of their three-dimensional nature, but have been shown in detail for other oncaeid species by a scanning electron microscope (cf. Böttger-Schnack 2001: fig. 9A, C, D), free margin of pockets ornamented with minute denticles (arrowed in Fig. 3G).

Mandible (Fig. 3C). With surface of coxa unornamented; gnathobase with five elements, numbered using capital letters in Fig. 3C: element A (ventral element) much shorter than ventral blade $\mathrm{B}$, with long setules; ventral blade $\mathrm{B}$ strong and broad, with row of setules on posterior surface; dorsal blade $\mathrm{C}$ strong and broad, with six or seven dentiform processes around distal margin and along distal half of dorsal margin; dorsal elements setiform, shorter spinulose (D), longer bipinnate (E).

Maxillule (Fig. 3D). Weakly bilobed, surface ornamented with few spinules. Inner lobe with three elements: outermost one spiniform and swollen at base, with three strong spinules at midregion and spinulose at distal part, middle element setiform and indistinctly bipinnate, innermost element bipinnate, located at some distance from others. Outer lobe with four elements: innermost element setiform and naked, element next to outermost spiniform and strong, with row of short spinules, two outermost elements setiform and pectinate, outermost element longest.

Maxilla (Fig. 3E). 2-segmented. Syncoxa unarmed, surface ornamented with few spinular rows and one large secretory pore; allobasis produced distally into slightly curved claw bearing two rows of strong spinules along inner margin; outer margin with stout naked seta almost extending to tip of allobasal claw; inner margin with slender spinulose seta and strong basally swollen spine ornamented with two spinular rows along medial margin and few long spinules at outer margin.

Maxilliped (Fig. 3F). 4-segmented, comprising syncoxa, basis and 2-segmented endopod. Syncoxa unarmed, posterior surface ornamented with few spinules. Basis robust, inner margin with two spiniform bipinnate elements unequal in length, proximal one more slender and slightly shorter than distal one; fringe of long pinnules along inner margin between distal spine and 

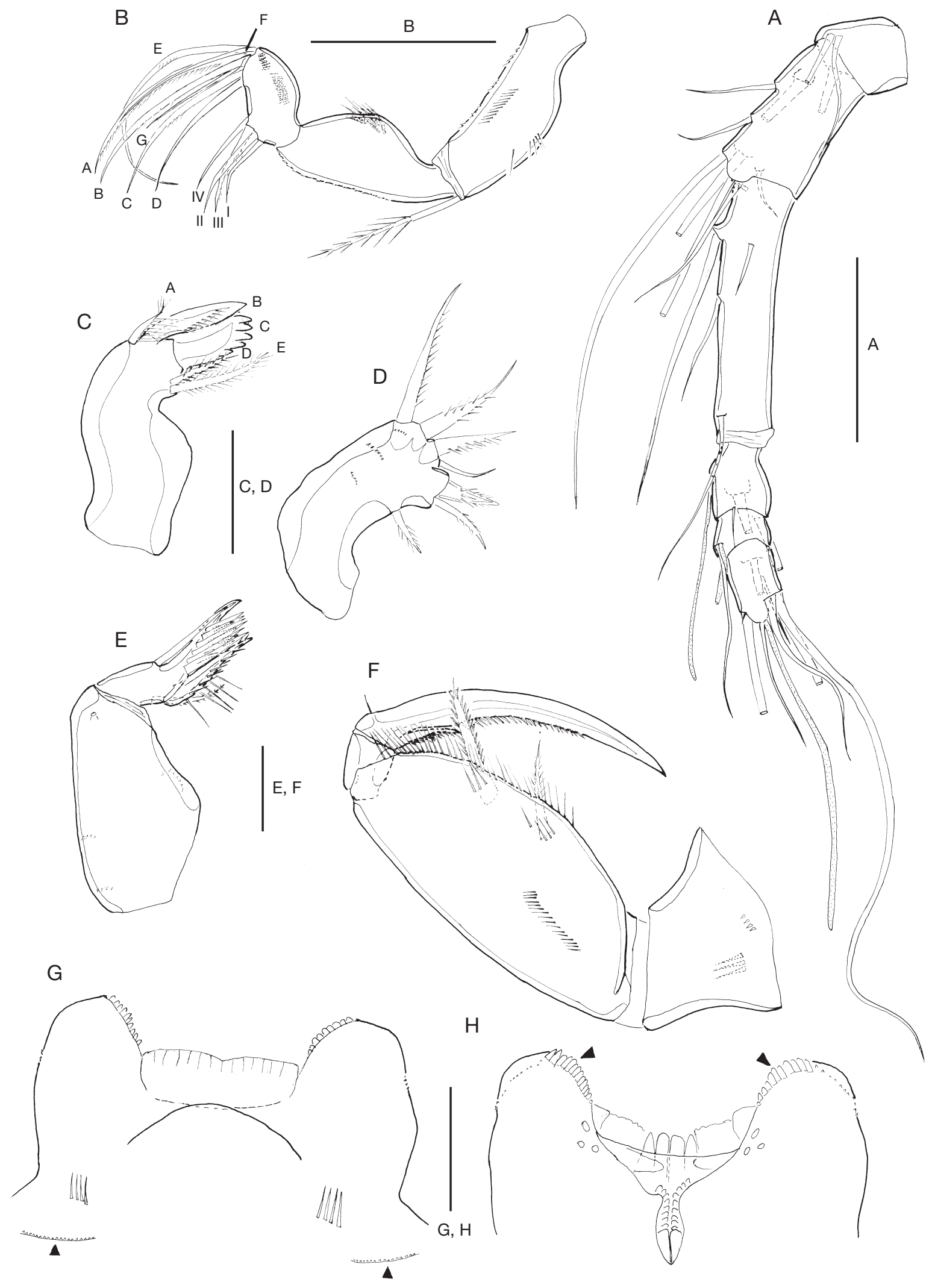

FIG. 3. - Triconia komo n. sp. female: A, antennule; B, antenna, anterior, distal elements on distal endopod segment numbered using capital letters, lateral elements indicated by Roman numerals; $\mathbf{C}$, mandible, individual elements indicated by capital letters; $\mathbf{D}$, maxillule; $\mathbf{E}$, maxilla; $\mathbf{F}$, maxilliped; $\mathbf{G}$, labrum, anterior, arrows indicating pockets; $\mathbf{H}$, labrum, posterior, arrows indicating dentiform processes. Abbreviations: see Material and methods. Scale bars: A, B, 50 m; $\mathrm{C}-\mathrm{H}, 20 \mu \mathrm{m}$. 
TABLE 1. - Leg armature formula.

\begin{tabular}{lllll}
\hline & Coxa & Basis & Exopod & Endopod \\
\hline P1 & $0-0$ & $1-I$ & $\mathrm{I}-0 ; \mathrm{I}-1 ; \mathrm{III}, \mathrm{I}, 4$ & $0-1 ; 0-1 ; 0, \mathrm{I}, 5$ \\
P2 & $0-0$ & $1-0$ & $\mathrm{I}-0 ; \mathrm{I}-1 ; \mathrm{II}, \mathrm{II}, 5$ & $0-1 ; 0-2 ; \mathrm{III}, 3$ \\
P3 & $0-0$ & $1-0$ & $\mathrm{I}-0 ; \mathrm{I}-1 ; \mathrm{II}, \mathrm{I}, 5$ & $0-1 ; 0-2 ; \mathrm{I}, \mathrm{II}, 2$ \\
P4 & $0-0$ & $1-0$ & $\mathrm{I}-0 ; \mathrm{I}-1 ; \mathrm{II}, \mathrm{I}, 5$ & $0-1 ; 0-2 ; \mathrm{I}, \mathrm{II}, 1$ \\
\hline
\end{tabular}

articulation with endopod and row of long spinules between distal and proximal spine; few short transverse rows of long setules on anterior surface and additional longitudinal row as illustrated in Fig. 3F. Distal endopod segment drawn out into long stout claw, with row of pinnules on proximal $2 / 3$ of concave margin; accessory armature consisting of minute, naked seta on outer proximal margin and unipectinate spine basally fused to inner proximal corner of claw.

Swimming legs 1-4. Biramous (Fig. 4A-D). With three-segmented rami. Intercoxal sclerites well developed, ornamented with paired row of few denticles distal corner in P1. Coxae and bases of P1-P4 with surface ornamentation as in Fig. 4A-D. Coxae of P1-P4 with raised secretory pore on posterior face near outer distal corner. Bases with short naked (P2) or long plumose (P1, P3, P4) outer seta; with anterior secretory pore near outer proximal corner. Coxa of $\mathrm{P} 4$ with tuft of very long fine setules posteriorly at outer proximal corner. Inner basal seta on P1 long and spiniform.

\section{Leg armature formula}

See Table 1.

Exopods. Outer margin of exopod segments with well-developed serrated hyaline lamella; inner margin of proximal exopod segments with long setules. Secretory pore located on posterior surface of distal segments; hyaline lamellae on outer spines well developed; outer and distal spines of P1 with subapical tubular extension; this extension lacking on proximalmost spine of exp-3. Distal spine equal in length to (P1) or shorter than (P2-P4) distal exopod segment. Length ranges of outer spine on exp-1 relative to outer spine on exp- 2 of $\mathrm{P} 3$ and $\mathrm{P} 4$ are given in Table 3 .

Endopods. Distal endopod segments with (P1-P3) or without (P4) single secretory pore on posterior surface. Distal margin of $\mathrm{P} 2-\mathrm{P} 4$ produced into conical process with apical pore, cone smaller in size and more slender on P4 (Fig. 4B-D). Length data of endopodal spines of holotype and five paratype females as shown in Table 2; length ranges of outer subdistal spine (OSDS) and outer distal spine (ODS) relative to distal spine (DS) are given in Table 3.

P5 (Fig. 2E). Comprising free exopod segment with few denticles on distal margin; very long and plumose outer basal seta. Exopod about 1.5 times longer than wide, bearing strong, curved inner seta and very long, slender outer seta, outer seta about 1.3 times longer than inner seta, reaching about to middle of genital double-somite.
P6 (Figs 2C; 13A). Represented by operculum closing off each genital aperture; armed with long spine and two minute spinules (only one of which is discernible under a light microscope).

\section{Male}

Body length. 503-507 $\mu \mathrm{m}$, based on two specimens. Sexual dimorphism in antennule, maxilliped, P5-P6 and in genital segmentation. Posterior margin of $\mathrm{P} 5$-bearing somite with paired row of minute denticles or spinules ventrally (Fig. 5E).

Prosome. 2.1 times the length of urosome, excluding caudal rami, about 1.9 times urosome length, including caudal rami (Fig. 5A). Integumental pores on prosome and urosome as figured (Fig. 5A).

Caudal rami. 1.7 times longer than wide, slightly shorter than in female; with length to width ratio and proportional lengths of caudal setae as in female. Dorsal surface of genital somite with five secretory pores as indicated in Fig. 5D. Surface of genital flaps ornamented with several rows of small spinules (Fig. 5E). Anal somite slightly wider than long as in female; with few rows of minute spinules on ventral surface.

Antennule (Fig. 5B) 4-segmented with distal segment corresponding to fused segments 4-6 of female. Armature formula 1 -[3], 2-[8], 3-[4], 4-[11+2ae+(1+ae)].

Maxilliped (Fig. 5F, G). 3-segmented, comprising syncoxa, basis and 1-segmented endopod. Syncoxa without surface ornamentation except for single secretory pore, unarmed. Basis robust, particularly inflated in proximal half forming bulbous swelling; anterior surface with 1-2 transverse spinular rows, and with small flat spinules along inner margin between proximal spine and articulation with endopod (Fig. 5F, G); posterior surface with three rows of spatulate spinules of graduated length along palmar margin (Fig. 5G); with two small naked setae of equal length inserted within longitudinal cleft. Endopod drawn out into long curved claw, concave margin unornamented: accessory armature consisting of short, unipectinate spine basally fused to inner proximal corner of claw, figured separately in Fig. 5F; claw with minute hyaline apex.

Swimming legs. With armature and ornamentation as in female; length data of endopodal spines of two males as shown in Table 2; length ranges of outer subdistal spine (OSDS) and outer distal spine (ODS) relative to distal spine are given in Table 4. Length ranges of outer spine on exp-1 relative to outer spine on exp-2 of P3 and P4 are given in Table 4.

P5 (Fig. 5C, D). Exopod not delimited from somite, shorter than that of female, armature as in female, but setal lengths much shorter than in female, with outer exopodal seta slightly longer than inner seta; outer basal seta bipinnate, much shorter than in female.

P6 (Fig. 5E). Represented by posterolateral flap closing off genital aperture on either side; covered by pattern of spinules 


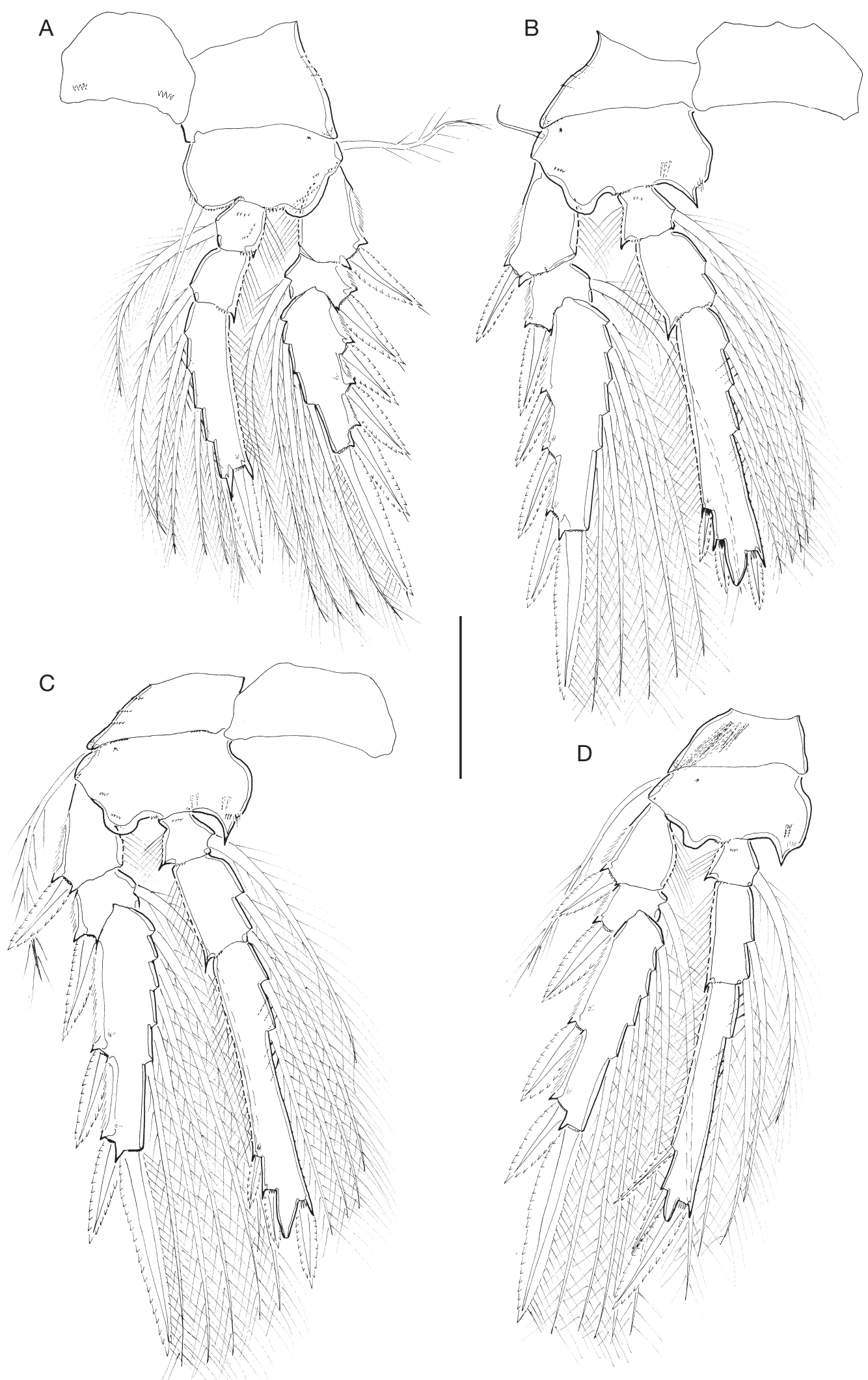

FIG. 4. - Triconia komo n. sp. female: A, P1, anterior; B, P2, anterior; C, P3, anterior; D, P4, anterior. Abbreviations: see Material and methods. Scale bar: 50 um. 


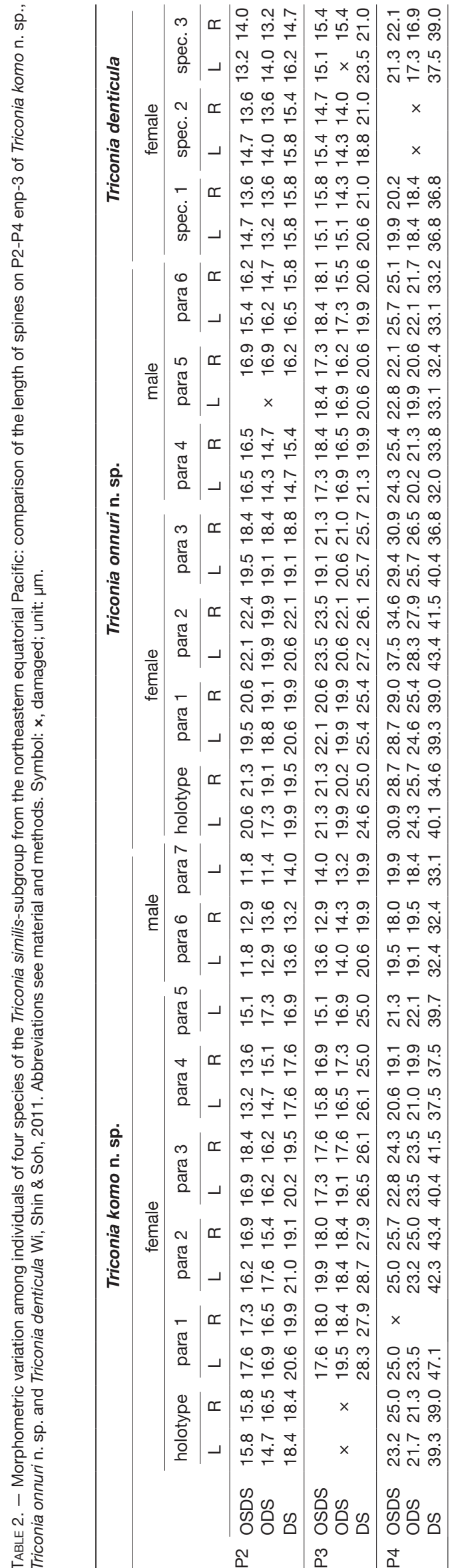

as shown in Fig. 5E; posterolateral corners protruding laterally and visible in dorsal aspect (Fig. 5A, D).

\section{REMARKS}

Triconia komo n. sp. belongs to the 1st group within the similissubgroup of Triconia, based on the proportional length of the distal spine on P2 enp-3, which is longer than the conical process in all species of this group (cf. Böttger-Schnack \& Machida 2011, see also introduction of the present paper). Among the four described species of this group, the females of T. komo n. sp. from the northeastern equatorial Pacific Ocean are most similar to T. hawii in the shape of the genital double-somite in dorsal view and the proportional lengths of the exopodal setae on P5. However, the females of the two species differ in: 1) body length, which is larger in T. komo n. sp. $(613-658 \mu \mathrm{m})$ than in T. hawii $(490-560 \mu \mathrm{m}) ; 2)$ the relative length of outer basal seta on $\mathrm{P} 5$, which is longer than the outer exopodal seta $(1.36: 1)$ in T. komo n. sp. reaching beyond the genital apertures in dorsal view (Fig. 2E), while the outer basal seta is shorter than the outer exopodal seta (0.84:1) in T. hawii, not reaching as far as the genital apertures (cf. Böttger-Schnack 1999, fig. 21B); 3) the length to width ratio of the caudal rami is slightly larger (about 1.8:1) than in T. hawii $(1.6: 1)$; 4) the relative length of caudal seta VI, which is about half the length of seta IV in T. komo n. sp., while seta VI is about $1 / 3$ the length of seta IV in T. hawii; and 5) in the form and length to width ratio of the genital double-somite, which is somewhat more elongate $(1.7: 1)$ than in $T$. hawii $(1.5: 1)$, with the narrower posterior part being longer $(1 / 3$ the length of genital double-somite) than in $T$. hawii $(1 / 4-1 / 5$ the length of genital double-somite).

In addition to the differences in morphological characters stated above morphometric differences are indicated in the proportional lengths of the exopodal spines on P3: the exopodal spine of exp-1 relative to the exopodal spine of exp-2 on P3, tends to be higher in T. komo n. sp. (0.77-0.87:1) than in T. hawii (0.69-0.78:1).

Another morphometric difference between T. komo n. sp. and $T$. hawii was assumed to exist in the endopodal spine lengths on P2 and P3 enp-3: the outer distal spine is reaching only slightly beyond the tip of the conical process in T. komo n. sp. (Fig. 4B, C), while this spine is reaching far beyond the tip of the cone in T. hawii (according to Böttger-Schnack \& Boxshall 1990: fig. 4C, D). However, a detailed re-examination of the swimming legs of T. hawii from the type locality in the Red Sea, based on the copepod material from the personal collection of R. Böttger-Schnack [cf. Böttger-Schnack 1999, p. 85 (c)], showed that the lengths of outer distal endopodal spines had not been figured entirely correctly in the original description by Böttger-Schnack \& Boxshall (1990: fig. 4C, D): the outer distal spine on P2 and P3 enp-3 is somewhat shorter than figured in that account and is not reaching far beyond the tip of the cone, but only slightly beyond the cone. In the redescription of the species from the Red Sea by Böttger-Schnack (1999) these morphometric characters had not be re-examined in detail and so the error was not noted. A detailed revision of the endopodal spine lengths on P2-P4 of 


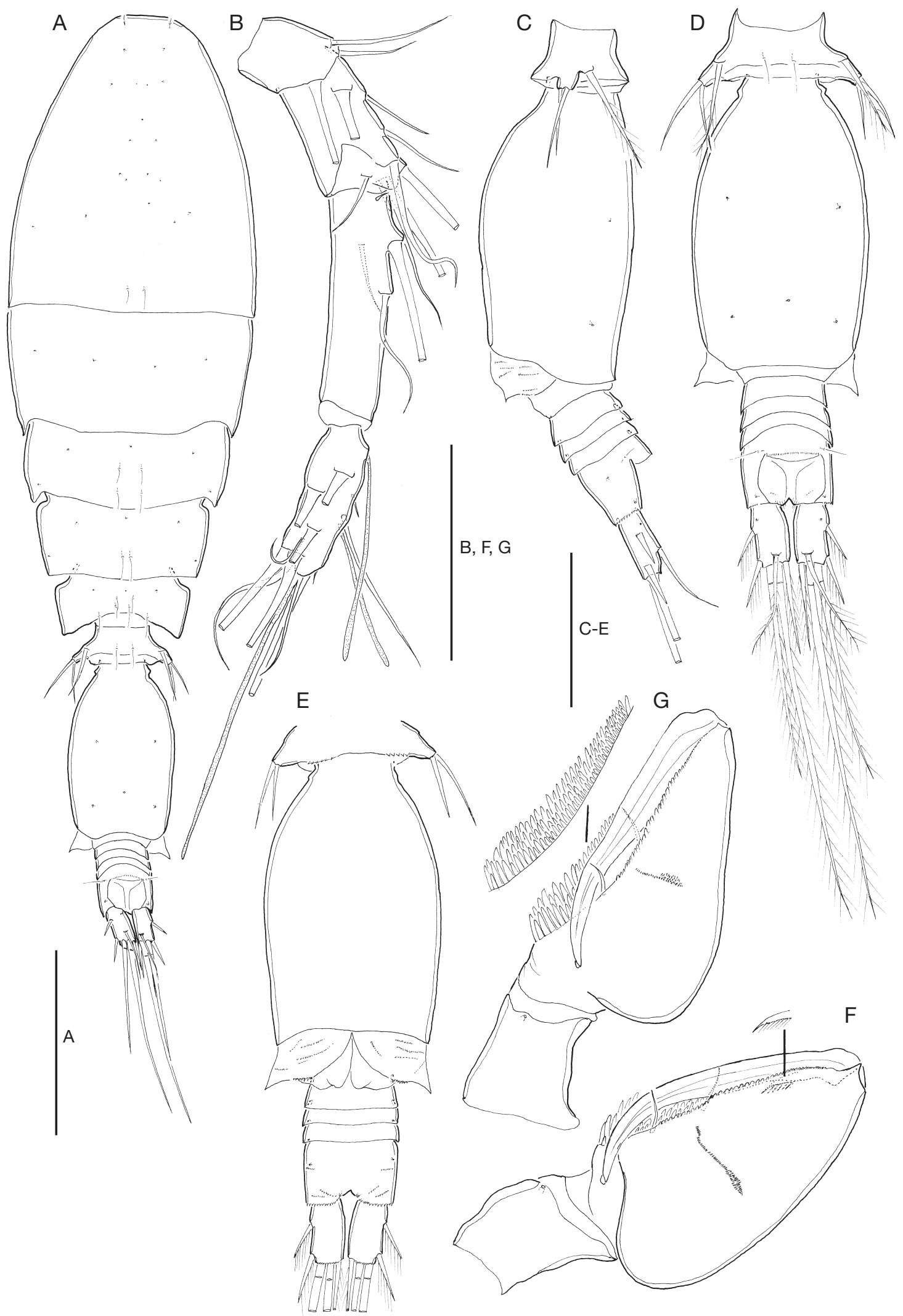

FIG. 5. - Triconia komo n. sp. male: A, habitus, dorsal; B, antennule; C, urosome, lateral; D, urosome, dorsal; E, urosome, ventral; F, maxilliped, anterior, spine fused to inner proximal corner of endopod (= claw) figured separately; G, maxilliped, medial view, ornamentation of palmar margin figured separately. Scale bars: A, $100 \mu \mathrm{m}, \mathrm{B}-\mathrm{F}, 50 \mu \mathrm{m}$. 
the genuine T. hawii from the Red Sea including new figures is in progress (Böttger-Schnack, pers. obs.). In the present paper, the updated measurements of outer distal spines on the endopods of P2-P4 of T. hawii were used to recalculate the length ratio of the outer distal to the distal spine on these legs, which, however, did not change significantly so that the given values are still valid for comparison with other species of the similis-subgroup (Table 3 ).

Further minor differences between T. komo n. sp. and T. hawii are found in several ornamentation details, such as of seta I on the second endopod segment of the antenna, of the innermost element on the outer lobe of maxillule and of the seta on the outer allobasal margin of the maxilla, all of which are naked in T. komo n. sp., but minutely ornamented in T. hawii.

Table 4 presents a comparison of morphological features for the described males of the similis-subgroup. The male of T. komo n. sp. differs from previously described four males of the similis-subgroup (including the male of T. onnuri n. sp. described below) by the following morphological characters: a smaller size $(503-507 \mu \mathrm{m})$ than males of $T$. similis and T. onnuri n. sp., which are longer than $570 \mu \mathrm{m}$; the pore pattern on the dorsal surface of the genital somite, with 5 pores compared to 3 in T. similis, T. onnuri $\mathrm{n}$. sp. and T. recta; the relative length of the inner seta on $\mathrm{P} 5$, which is shorter than the outer seta in the male of T. komo n. sp., but slightly longer in T. hawii; the length ratio of seta VI to seta VII on the caudal ramus, which is about 1 in the male of T. komo n. sp., while it is less than 1 in males of $T$. hawii and $T$. recta. Additional small differences between the four species are found in the few minute denticles or spinules on the ventral face of the P5-bearing somite in T. komo n. sp., which are absent in the other males except T. onnuri $\mathrm{n}$. sp., and in the length to width ratio of the caudal ramus (cf. Table 4).

The male of T. denticula, representing another species of the similis-subgroup, is still unknown. Females of T. denticula were found to co-occur with T. komo n. sp. in the study area during the present study, but were very rare, while T. komo n. sp. was common. No mating pairs of either species were found, which would have provided clear evidence of the identity of the male; however, the male of T. komo n. sp. was tentatively identified on the basis of the relative lengths of caudal seta VI, being similar to seta VII as in female of T. komo n. sp., while in female of $T$. denticula, seta VI is much shorter than seta VII. The proportional spine lengths on the endopods of P2-P4, which were examined in detail for both sexes in the present study, are not helpful for a distinction, as they are similar between females of the two species (Table 3); however, the ratio of the outer distal spine to distal spine on P4 enp-3 in the male (Table 4) appears to be more similar to T. komo n. sp. than to T. denticula. Also, the proportional spine lengths on the exopods of $\mathrm{P} 3$ and $\mathrm{P} 4$, which are proposed as new diagnostic characters for the identification of oncaeid males, appear to be more similar to T. komo n. sp. than to T. denticula (Tables 3, 4). However, in view of the limited number of male individuals examined for these morphometric characters, their variability is still insufficiently known and support for a posi- tive identification can only be given in further studies on a larger number of specimens in order to more clearly define the indicative value of these characters.

Triconia onnuri $\mathrm{n}$. sp.

(Figs 6-9; 13B, C; Tables 2-4)

urn:Isid:zoobank.org:act:515ECE8F-6AAE-47DD-AF7B-55D899441DC7

TYPE LOCALITY. - Northeastern equatorial Pacific Ocean $\left(10^{\circ} 30^{\prime} \mathrm{N}\right.$, $\left.131^{\circ} 20^{\prime} \mathrm{W}, 0-100 \mathrm{~m}\right)$.

TYPE MATERIAL. - Holotype. 1 \%; NIBRIV0000838008; 10³0’N, $131^{\circ} 20^{\prime} \mathrm{W} ; 0-100 \mathrm{~m}$; dissected and mounted on 10 slides, collected from the type locality on 21.VIII.2009 by D. J. Ham.

Paratypes. 3 \% ; NIBRIV0000838009-011; $10^{\circ} 30^{\prime} \mathrm{N}, 131^{\circ} 20^{\prime} \mathrm{W}$; $0-100 \mathrm{~m}$; each dissected and mounted on 9 or 10 slides, respectively (lost a slide of urosome with P5 of the third paratype). - $30^{\prime \prime}$; NIBRIV0000838012-014; 10³0'N, $131^{\circ} 20^{\prime} \mathrm{W} ; 0-100 \mathrm{~m}$; each dissected and mounted on 10 slides, respectively. -4 \% $30^{7} \mathrm{kept}$ in one vial in alcohol, MNHN-IU-2019-2283. All specimens are from the type locality.

ETYMOLOGY. - The species is named after research vehicle 'Onnuri' of the Korea Institute of Ocean Science and Technology (KIOST) to recognize contributions to research activities in the northeastern equatorial Pacific Ocean.

\section{DESCRIPTION}

Female

Body length. 784-823 $\mu \mathrm{m}$, based on four specimens.

Exoskeleton moderately chitinized. Prosome about 1.9 times length of urosome, excluding caudal rami 1.7 times urosome length including caudal rami. P2-bearing somite without conspicuous dorsoposterior projection in lateral aspect (Fig. 6B). Integumental pores on prosome as indicated in Fig. 6A. Pleural areas of $\mathrm{P} 4$-bearing somite with rounded posterolateral corners. One pair of secretory pores discernible on first postgenital somite (Fig. 6D).

Genital double-somite. 2.0 times as long as maximum width (measured in dorsal aspect) and about 2.2 times as long as postgenital somites combined; largest width measured at anterior one third; posterior part tapering gradually (Fig. 6C); surface covered with numerous minute pores or pits near genital apertures (inset of Fig. 13B). Paired genital apertures located dorsally at about $1 / 3$ of distance from anterior margin of genital double-somite (Fig. 6C); armature represented by one long spine and minute spinule (Fig. 13B). Secretory pores on dorsal surface as indicated in Fig. 6C.

Anal somite. About 1.4 times wider than long; slightly longer than caudal rami (Fig. 6C). Ornamentation as in T. komo n. sp.

Caudal ramus. About two times as long as wide. Seta VII about half length of seta IV; seta VI almost same length as seta VII, swollen at base (arrowed in Fig. 6F). 


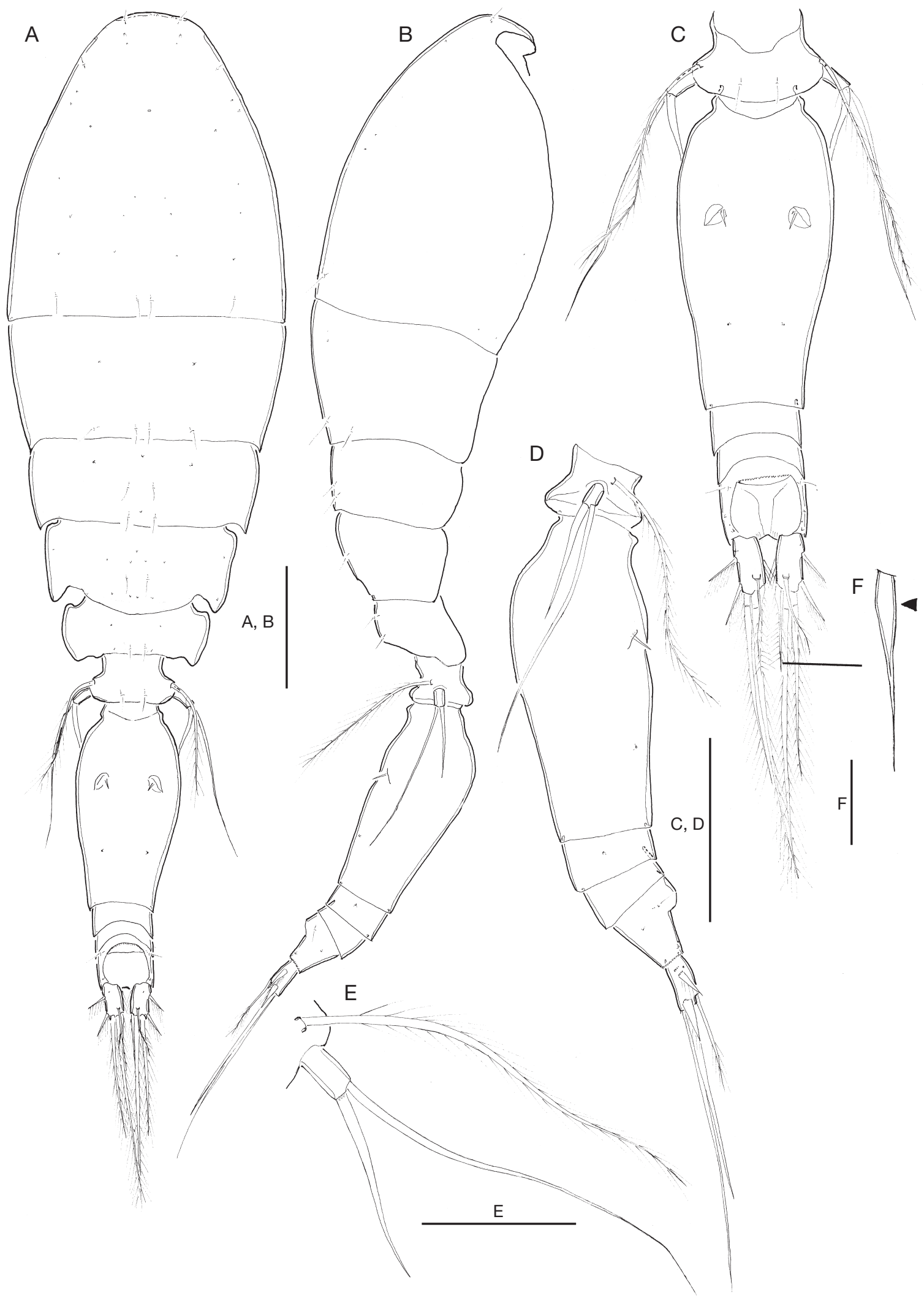

FIG. 6. - Triconia onnuri n. sp. female: A, habitus, dorsal; B, habitus, lateral; C, urosome, dorsal; D, urosome, lateral; E, P5, dorsal view; F, seta VI on caudal ramus, arrow indicating swollen base. Scale bars: A-D, $100 \mu \mathrm{m} ; \mathrm{E}, 50 \mu \mathrm{m} ; \mathrm{F}, 20 \mu \mathrm{m}$. 

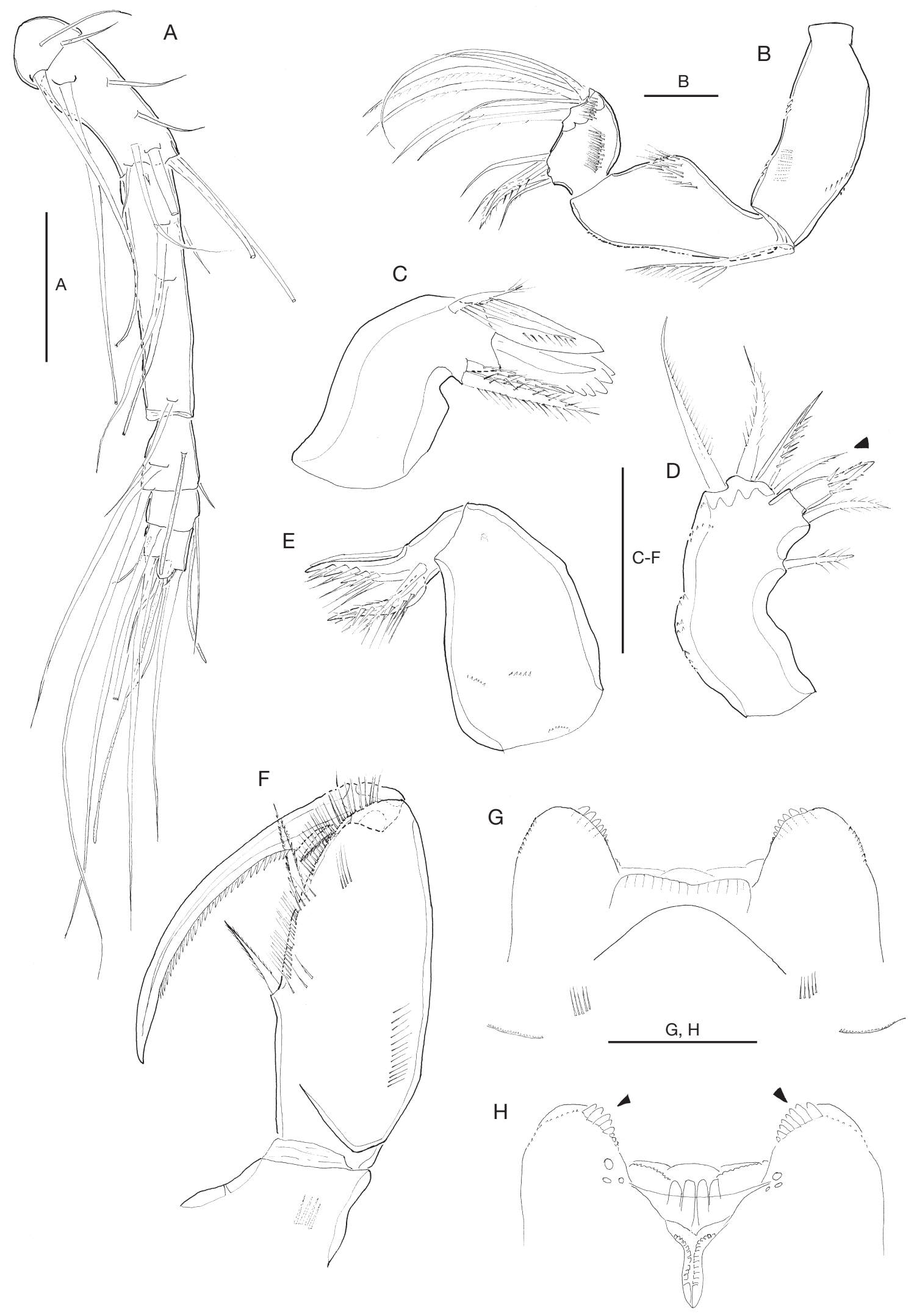

FIG. 7. - Triconia onnuri n. sp. female: A, antennule; B, antenna, posterior; C, mandible; $\mathbf{D}$, maxillule, arrow indicating ornamentation of innermost element on outer lobe; E, maxilla; F, maxilliped; G, labrum, anterior; $\mathbf{H}$, labrum, posterior, arrows indicating dentiform processes. Scale bars: A, C-H, $50 \mu \mathrm{m}$; B, 20 um. 

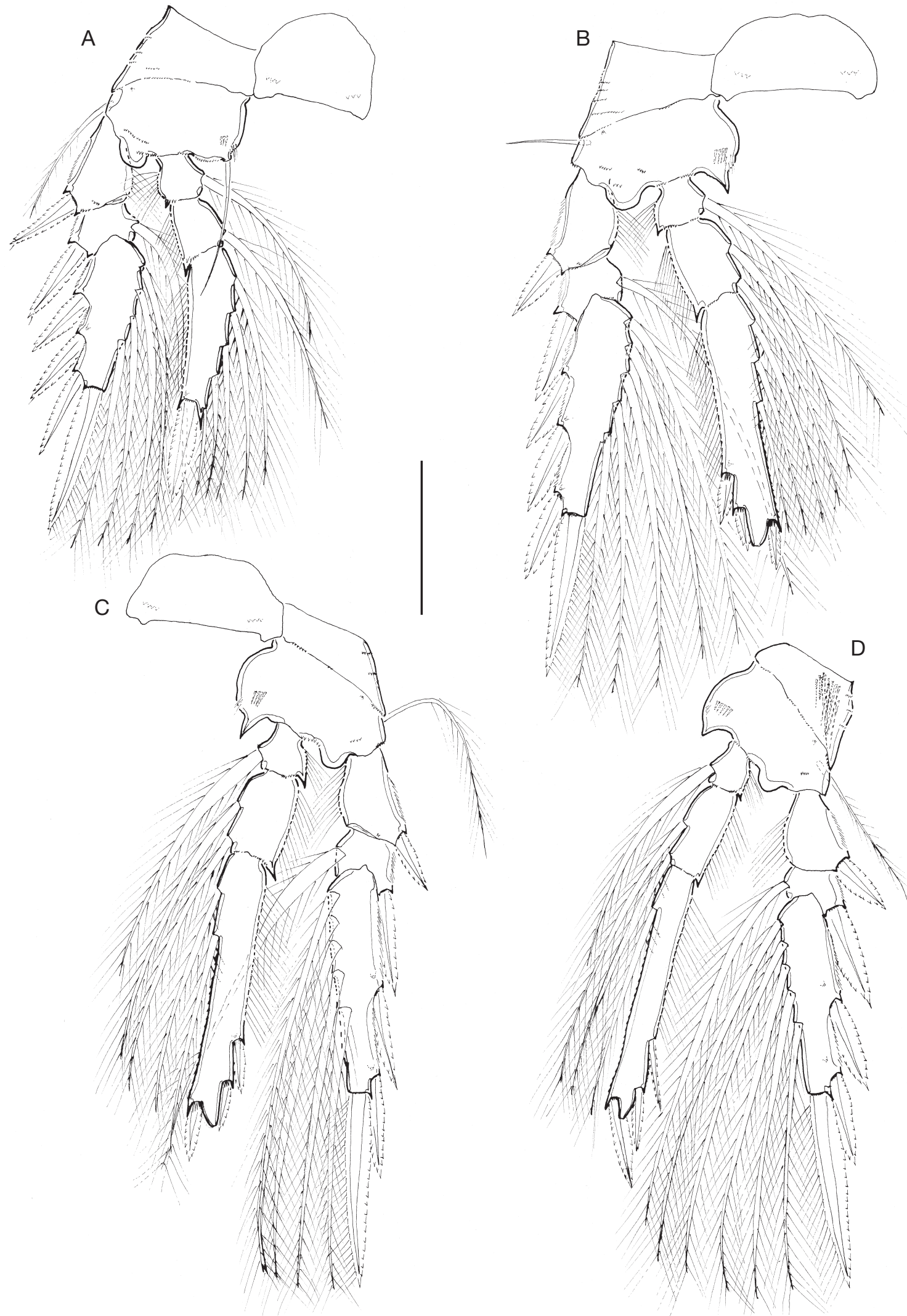

FIG. 8. - Triconia onnuri n. sp. female: A, P1, anterior; B, P2, anterior; C, P3, anterior; D, P4, anterior. Abbreviations: see Material and methods. Scale bar: 50 um. 
TABLE 3. - Comparison of morphometric ratios for females of species of the Triconia similis-subgroup from the equatorial Pacific (present study: ) with specimens from other regions (T. denticula Wi, Shin \& Soh, 2011, T. similis (Sars, 1918), T. hawii (Böttger-Schnack \& Boxshall, 1990), and T. recta Böttger-Schnack, 1999). Abbreviations see material and methods. Symbols: * , for number of specimens measured see Table 2; $\dagger$, values from re-examination of type material (see under "Remarks" of T. denticula Wi, Shin \& Soh, 2011); \#, values from re-examination of copepod material from type locality (see under "Remarks" of T. komo); $\#$ \#, values from re-examination of original drawings of female neotype.

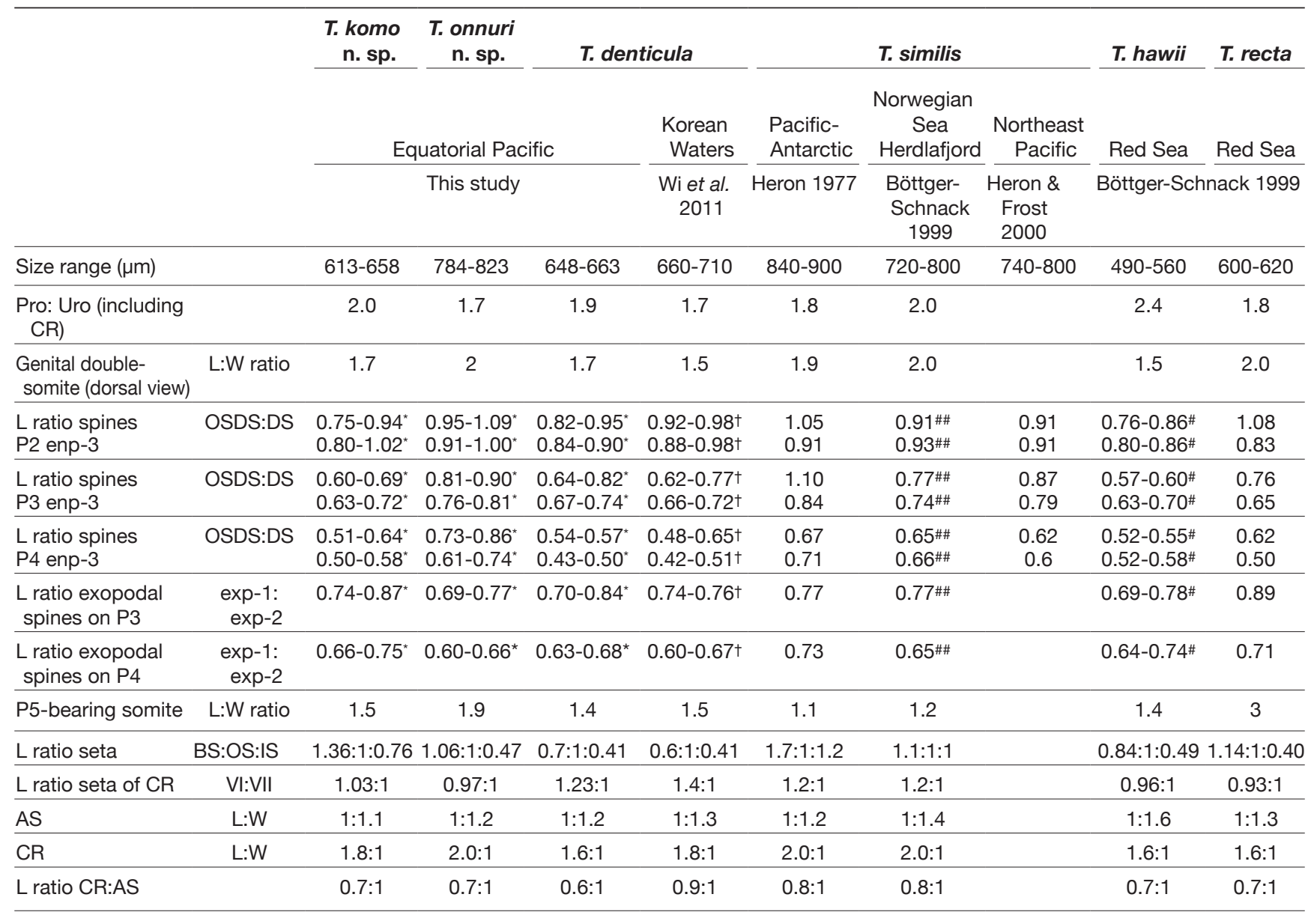

Antennule (Fig. 7A). 6-segmented. Armature formula as for T. komo n. sp.

Antenna (Fig. 7B). 3-segmented. Distal endopod segment with armature and ornamentation as in T. komo n. sp., except for seta I of lateral armature sparsely pinnate, and seta III bipinnate at distal part.

Labrum (Fig. 7G, H). Similar to T. komo n. sp., except for each lobe with stronger and fewer dentiform processes than in T. komo n. sp.

Mandible (Fig. 7C). Maxillule (Fig. 7D) and maxilla (Fig. 7E) as for T. komo n. sp., except for innermost element on outer lobe of maxillule ornamented with small spinules (arrowed in Fig. 7D).

Maxilliped (Fig. 7F). Similar to T. komo n. sp., basis with two bipinnate spiniform elements, nearly equal in length, distal one slightly longer. Distal endopod segment (claw) with row of strong pinnules along proximal $4 / 5$ of concave margin.

Swimming legs 1-4. Biramous (Fig. 8A-D). With armature as in T. komo n. sp. Intercoxal sclerites of P1-P3 ornamented with few spinules on posterior face (Fig. 8A, B, C); intercoxal sclerite of P4 not observed. Coxae and bases of P1-P4 with ornamentation as shown in Fig. 8A-D. Basis of P4 with outer seta shorter than in T. komo n. sp. (Fig. 8D).

Exopods. Similar to T. komo n. sp., except for length of outer spine on P3 exp-1 shorter than in T. komo n. sp. (Fig. 8C). Length ratio of outer spine on exp-1 relative to outer spine on exp- 2 of P3 and P4 somewhat smaller than in T. komo n. sp. (Table 3).

Endopods. Distal margin of P2-P4 produced into conical process with apical pore. Length ratios of spines different from T. komo n. sp. with length data of spines of five specimens as shown in Table 2; length ranges of outer subdistal spine 


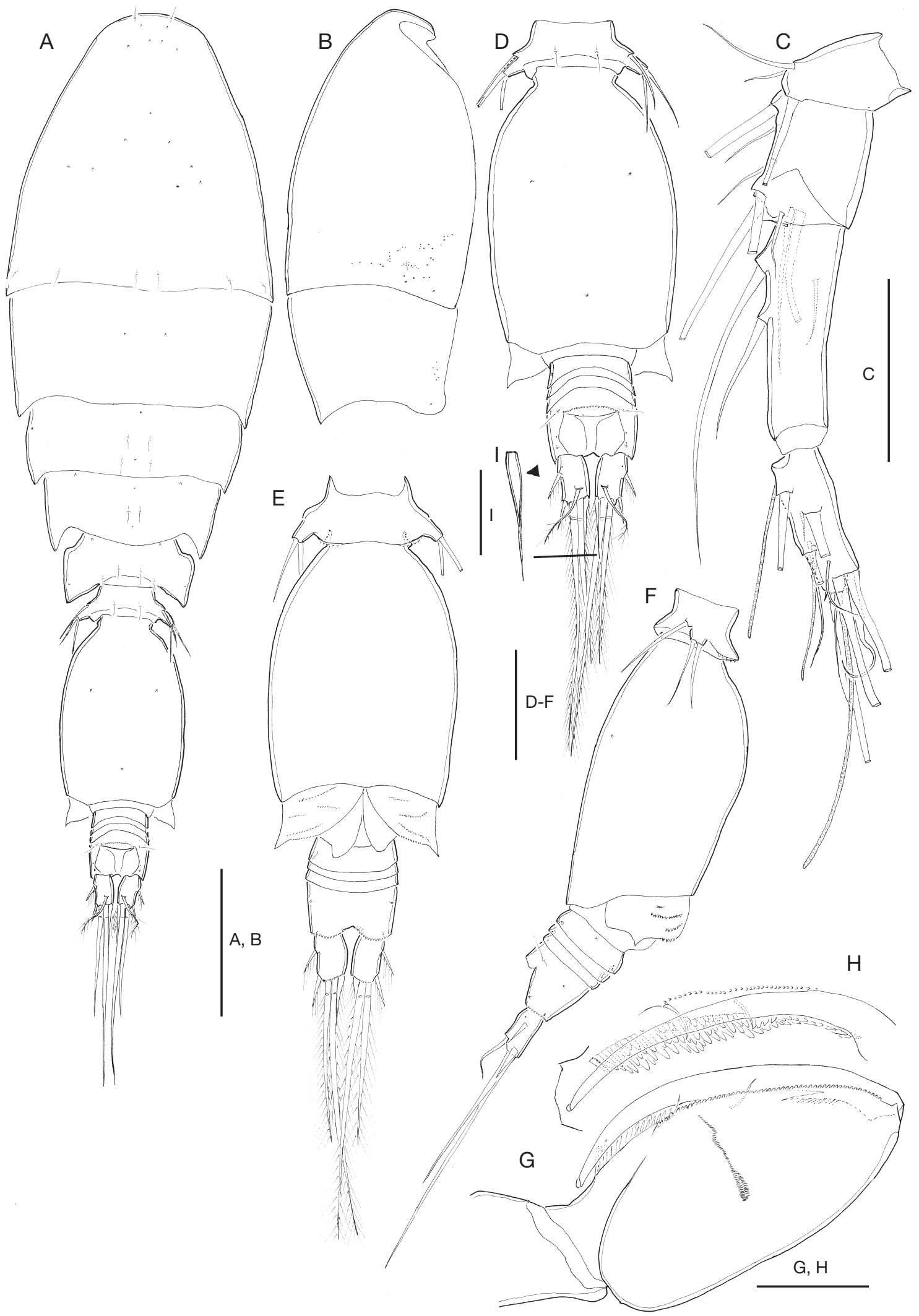

FIG. 9. - Triconia onnuri n. sp. male: A, habitus, dorsal; B, cephalosome and P1-bearing somite, lateral; C, antennule; D, urosome, dorsal; E, urosome, ventral; F, urosome, lateral; G, maxilliped, anterior; H, maxilliped, medial view; I, seta VI on caudal ramus, arrow indicating swollen base. Scale bars: A, B, 100 um; $\mathrm{C}-\mathrm{H}, 50 \mu \mathrm{m} ; \mathrm{I}, 20 \mu \mathrm{m}$. 
TABLE 4. - Comparison of morphometric ratios for males of species of the Triconia similis-subgroup from the equatorial Pacific (present study) with specimens from other regions (T. similis (Sars, 1918) material from neotype locality, T. hawii (Böttger-Schnack \& Boxshall, 1990), and T. recta Böttger-Schnack, 1999). Abbreviations see Material and methods.

\begin{tabular}{|c|c|c|c|c|c|c|}
\hline & & T. komo n. sp. & T. onnuri n. sp. & T. similis & T. hawii & T. recta \\
\hline & & \multicolumn{2}{|c|}{ Equatorial Pacific } & $\begin{array}{c}\text { Norwegian Sea } \\
\text { Herdlafjord }\end{array}$ & Red Sea & Red Sea \\
\hline & & \multicolumn{2}{|c|}{ This study } & \multicolumn{3}{|c|}{ Böttger-Schnack 1999} \\
\hline Size range $(\mu \mathrm{m})$ & OSDS:DS & $503-507$ & $570-604$ & $570-604$ & $480-490$ & $470-520$ \\
\hline Genital somite: No. of pores & ODS:DS & 5 & 3 & 3 & 5 & 3 \\
\hline$L$ ratio spines & OSDS:DS & $0.84-0.97^{*}$ & $0.93-1.13^{*}$ & - & - & - \\
\hline P2 enp-3 & ODS:DS & $0.82-1.03^{*}$ & $0.93-1.05^{\star}$ & - & - & - \\
\hline$L$ ratio spines & OSDS:DS & $0.65-0.70^{*}$ & $0.81-0.93^{*}$ & - & - & - \\
\hline P3 enp-3 & ODS:DS & $0.67-0.72^{*}$ & $0.75-0.87^{*}$ & - & - & - \\
\hline$L$ ratio spines & OSDS:DS & $0.56-0.60^{*}$ & $0.68-0.78^{*}$ & - & - & - \\
\hline P4 enp-3 & ODS:DS & $0.56-0.60^{*}$ & $0.60-0.67^{*}$ & - & - & - \\
\hline $\mathrm{L}$ ratio exopodal spines on $\mathrm{P} 3$ & exp-1: exp-2 & $0.86-0.9^{*}$ & $0.72-0.77^{*}$ & No data & No data & No data \\
\hline $\mathrm{L}$ ratio exopodal spines on $\mathrm{P} 4$ & exp-1: exp-2 & $0.70-0.77^{*}$ & $0.62-0.72^{*}$ & No data & No data & No data \\
\hline P5 & $\begin{array}{r}\text { L ratio seta } \\
\text { BS:OS:IS }\end{array}$ & 1.3:1:0.79 & 1.17:1:0.92 & 1.29:1:0.94 & $1.57: 1: 1.07$ & $1.22: 1: 0.72$ \\
\hline$\underline{\mathrm{L} \text { ratio seta of } \mathrm{CR}}$ & VI:VII & 1.03:1 & $1.04: 1$ & $1: 1$ & $0.81: 1$ & 0.83:1 \\
\hline CR & $\mathrm{L}: \mathrm{W}$ & $1.7: 1$ & $1.4: 1$ & $1.7: 1$ & $1.4: 1$ & 1.6:1 \\
\hline & $\mathrm{L}$ ratio seta VI: CR & $1.8: 1$ & 1.8:1 & 1.5:1 & $1.4: 1$ & $2.0: 1$ \\
\hline
\end{tabular}

(OSDS) and outer distal spine (ODS) relative to distal spine (DS) given in Table 3.

P5 (Fig. 6E). With outer basal seta very long and plumose at distal part; exopod segment free. Exopod about 1.9 times longer than wide, bearing two naked setae, bearing stout inner seta and extremely long, slender outer seta about twice of length of inner seta, reaching $4 / 5$ the length of genital double-somite from anterior margin, as far as secretory pores on dorsal surface.

P6 (Fig. 6F). Represented by operculum closing off each genital aperture, ornamented with long spine and minute spinule (Fig. 13B).

\section{Male}

Body length. 570-604 $\mu \mathrm{m}$, based on three specimens. Sexual dimorphism in antennule, maxilliped, P5-P6, caudal ramus, and in genital segmentation. Prosome 1.8 times urosome length, including caudal rami (Fig. 9A). Cephalosome and P1 bearing somite with conspicuous lateral patterns of pore patches (Figs 9B; 13C). Posterior margin of P5-bearing somite with paired row of minute denticles or spinules ventrally (Fig. 9E).

Genital somite (Fig. 9D). About 1.5 times longer than wide.

Caudal rami. About 1.4 times longer than wide, shorter than in female. Caudal seta with proportional lengths as in female, seta VI swollen at base as in female (arrowed in Fig. 9I). Dorsal surface of genital somite with three secretory pores as indicated in Fig. 9D. Surface of genital flaps ornamented with several rows of small spinules (Fig. 9E, F).
Antennule (Fig. 9C). 4-segmented; armature formula as for T. komo n. sp.

Maxilliped (Fig. 9G, H). 3-segmented. Surface ornamentation on syncoxa not discernible, except for single secretory pore at inner distal margin. Basis robust, with small naked setae within longitudinal cleft, proximal seta about same length as distal one; anterior surface with one-two transverse spinular rows and row of small flat spinules along inner margin; posterior surface with rows of short spinules of graduated length along palmar margin.

Swimming legs. With armature and ornamentation as in female, length data of endopodal spines of three males as shown in Table 2; length ranges of outer subdistal spine (OSDS) and outer distal spine (ODS) relative to distal spine given in Table 4; generally similar to females (cf. Table 3).

P5 (Fig. 9D, F). Exopod not delimited from somite, shorter than in female; outer exopodal seta unornamented and almost equal in length to inner seta; outer basal seta naked and much shorter than in female.

P6. Represented by posterolateral flap closing off genital aperture on either side; covered by pattern of spinules as shown in Fig. 9E; posterolateral corners protruding laterally and visible in dorsal aspect (Fig. 9A, D).

\section{REMARKS}

Among species of the similis-subgroup of Triconia, T. onnuri n. sp. is closely related to T. similis, based on the body size and the form of the genital double-somite in the female, but differs 
in the relative lengths of the outer exopodal seta and the outer basal seta on $\mathrm{P} 5$, with both setae reaching over half the distance from anterior to posterior margin of the genital double-somite, and the form of caudal seta VI, which is swollen at its base. The combination of these characters separates the new species also from other described species of the similis-subgroup. Furthermore, T. onnuri $\mathrm{n}$. sp. can be identified by the length to width ratio of P5 exopod, which is intermediate (1.9:1) between those of other species of the similis-subgroup (most are less than 1.5:1, except 3:1 in T. recta); and in some minor differences in the proportional spine lengths on the endo- and /or exopods of P2-P4. Especially on the endopod of P4, the length ratio values of outer subdistal spine (OSDS) relative to distal spine (DS) is higher in T. onnuri n. sp. (OSDS:DS=0.73-0.86:1) than the range of single values reported for $T$. similis from three studies (OSDS:DS=0.62-0.67:1, Table 3).

The male of T. onnuri n. sp. shows a distinct modification of seta VI on the caudal ramus, which is basally swollen (Fig. 8I) as in the female (Fig. 5F). Modifications in the form of caudal setae have not been observed in other species of Triconia so far, but have been reported for other oncaeid species, such as species of Spinoncaea (Böttger-Schnack 2003) and Epicalymma (Böttger-Schnack 2009), where they occur in both sexes as well. Thus, in T. onnuri n. sp., the modification of the caudal setae can be used as an additional tool for separating the species from closely related species within the genus. Also in the male, the proportional spine lengths on the endopod of P2-P4 and the length range of the exopodal spines on exp-1 of P3-P4 are similar to the female.

Triconia denticula Wi, Shin \& Soh, 2011

(Figs 10-12; Tables 2, 3)

Triconia denticula Wi, Shin \& Soh, 2011: 590-595, figs 2-4, 9A, $\mathrm{B}, \mathrm{F}($ ( ) $)$.

TyPe LOCALITY. - East China Sea (south of Cheju Island)

Material EXAMINED. - East China Sea. 3 \% ; NIBRIV0000838015-017; each dissected and mounted on 10 slides, respectively; all specimens collected from the northeastern equatorial

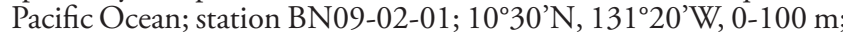
21.VII.2009 by D. J. Ham.

\section{DESCRIPTION}

\section{Female}

Body length. 648-663 $\mu \mathrm{m}$, based on three specimens. Exoskeleton moderately chitinized. Prosome about 2.1 times length of urosome, excluding caudal rami 1.9 times urosome length including caudal rami. P2-bearing somite without conspicuous dorsoposterior projection in lateral aspect (Fig. 10B). Integumental pores on prosome as indicated in Fig. 10A. Pleural areas of P4-bearing somite with rounded posterolateral corners. One pair of secretory pores discernible on first postgenital somite (Fig. 10D).

Genital double-somite. 1.7 times as long as maximum width (measured in dorsal aspect) and about 2.1 times as long as postgenital somites combined; largest width measured just posterior to mid-level; lateral margins of genital double-somite sinuous anterior to level of maximum width, tapering posteriorly (Fig. 10C); dorsal and lateral surface ornamented with several rows of spinules (Fig. 10C, D); anterior part of genital double-somite protruding dorsally (Fig. 10D). Paired genital apertures located at about $2 / 5$ of distance along genital doublesomite from anterior margin. Paired secretory pores on dorsal surface located at about $2 / 3$ of distance along double-somite from anterior margin (arrowed in Fig. 10C).

Anal somite. Slightly wider than long; slightly longer than caudal rami (Fig. 10C). Ornamentation as in T. komo n. sp. (Fig. 10C, D).

Caudal ramus. About 1.6 times as long as wide; with seta VII slightly longer than half the length of seta IV and shorter than seta VI (Fig. 10C).

Antennule. 6-segmented, armature formula as for T. komo n. sp. (Fig. 11A).

Antenna (Fig. 11B). 3-segmented. Distal endopod segment with distal armature consisting of five curved setae, long naked (E), entire unipinnate $(A)$, sparsely pinnate $(B-D)$, setae A-D of graduated length with seta $\mathrm{D}$ shortest, and two slender bare setae $(F+G)$, seta $G$ shortest.

Labrum (Fig. 11G, H). With medial concavity between lobes covered anteriorly by single long hyaline lamella, lobes with dentiform processes around outer ventral margin more slender than in T. komo n. sp. Anterior surface with paired row of long setules and free margin of integumental pockets either side of median swelling ornamented with minute denticles. Posterior wall of medial concavity ornamented with four long sclerotized "teeth", posterior surface with group of four secretory pores located on proximal part of each lobe (Fig. 11H).

Mandible (Fig. 11C). Maxillule (Fig. 11D) and maxilla (Fig. 11E) as for T. komo n. sp., with slight differences in surface ornamentation of coxa on mandible, and on syncoxa on maxilla.

Maxilliped (Fig. 11F). With ornamentation of syncoxa as figured. Basis with two bipinnate spiniform elements, nearly equal in length; fringe of long pinnules between distal seta and articulation with endopod, row of long spinules between proximal and distal setae; short transverse row of long setules near distal seta on anterior surface and additional longitudinal row near outer margin. Distal endopod segment (claw) with row of pinnules along proximal $2 / 3$ of concave margin. Other elements as in T. komo n. sp.

Swimming legs 1-4 biramous (Fig. 12A-D). With armature and ornamentation as in T. komo n. sp. Intercoxal sclerites well developed, without ornamentation. Bases with short (P1, P2, P4) or very long (P3) outer seta. 


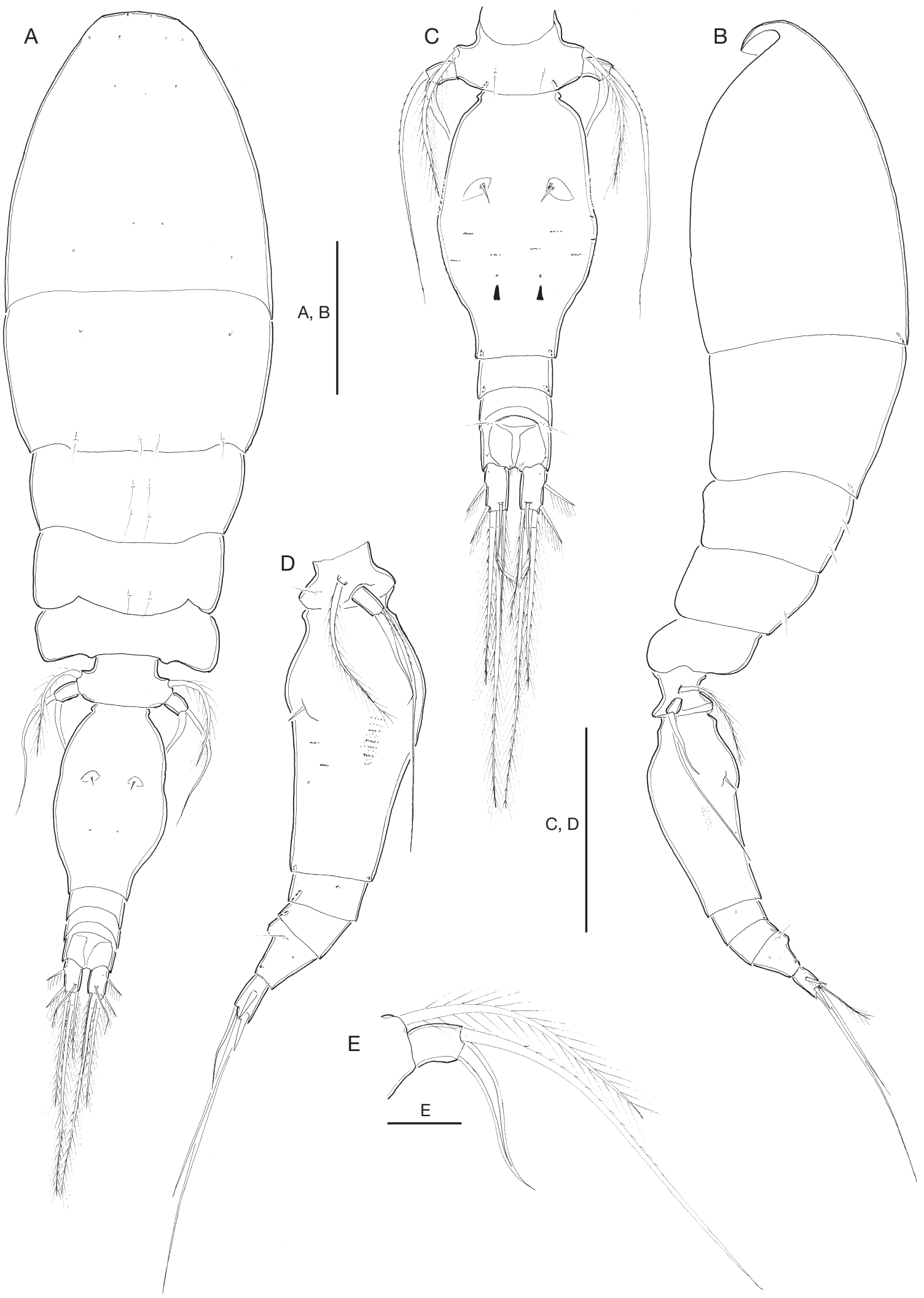

FIG. 10. - Triconia denticula Wi, Shin \& Soh, 2011. female: A, habitus, dorsal; B, habitus, lateral; C, urosome, dorsal, arrows indicating secretory pores; D, urosome, lateral; E, P5, dorsal view. Scale bars: A-D, $100 \mu \mathrm{m}, \mathrm{E}, 20 \mu \mathrm{m}$. 

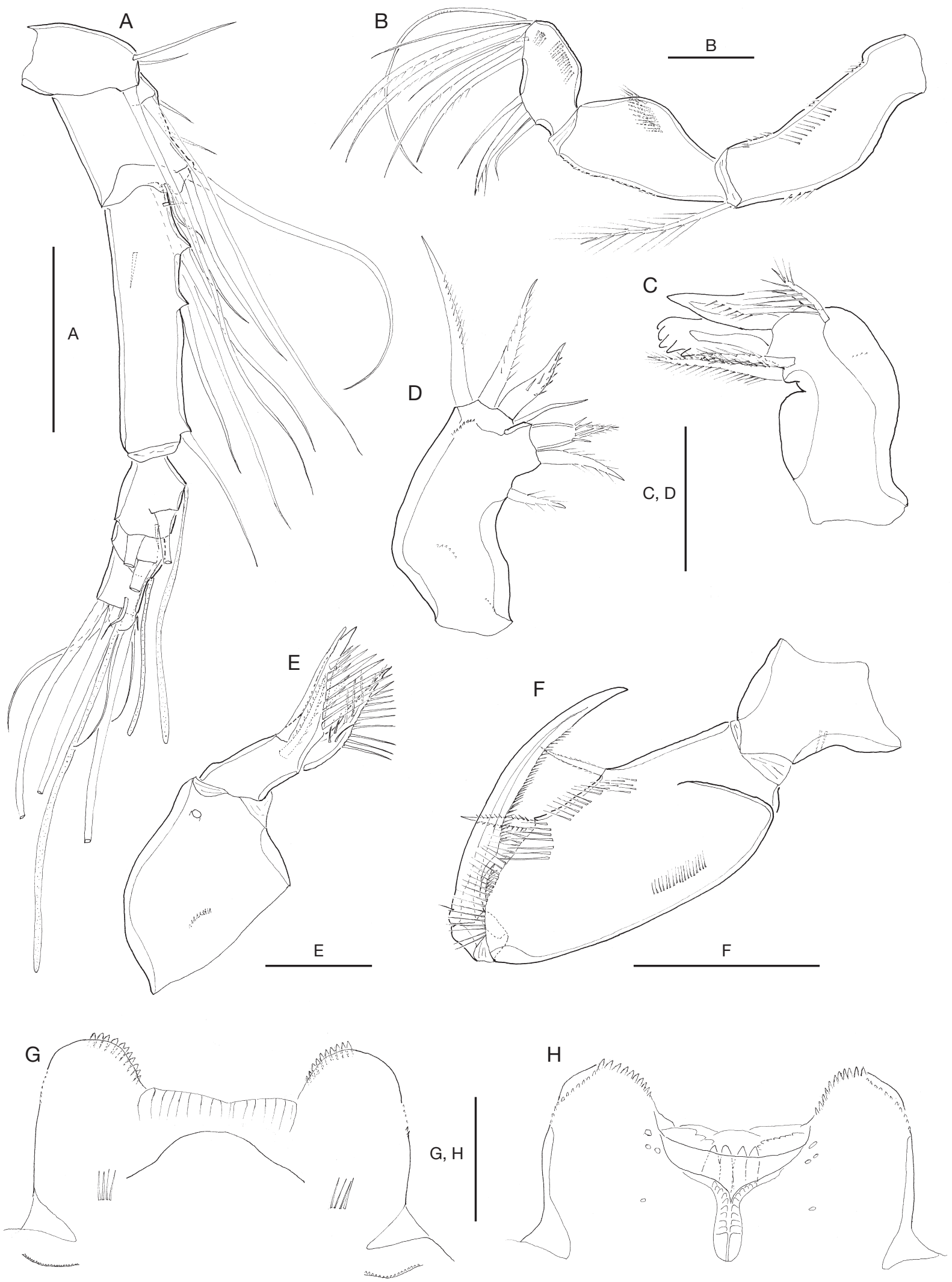

FIG. 11. - Triconia denticula Wi, Shin \& Soh, 2011, female: A, antennule; B, antenna, anterior; C, mandible; D, maxillule; E, maxilla; F, maxilliped; G, labrum, anterior; H, labrum, posterior. Scale bars: A, F, $50 \mu \mathrm{m}$; B-E, G, H, $20 \mu \mathrm{m}$. 
Exopods. With ornamentation similar to T. komo n. sp. Distal spine almost equal in length to (P4) or shorter (P1, P2, P3) than distal exopod segment. Length of exopodal spine on exp-1 and exp-2 of P3 and P4 shorter than in T. komo n. sp. (Fig. 12C, $\mathrm{D})$. Length ratio of outer spine on exp-1 relative to outer spine on exp-2 of P3 and P4 similar to T. komo n. sp. (Table 3).

Endopods. Distal margin of P2-P4 produced into conical process (Fig. 12B-D), process with apical pore. Length data of spines on P2-P4 enp-3 of three specimens as shown in Table 2; length ranges of outer subdistal spine (OSDS) and outer distal spine (ODS) relative to distal spine (DS) given in Table 3.

P5 (Fig. 10E). Comprising long plumose outer basal seta and free unornamented exopod segment. Exopod longer than wide, bearing long slender seta (outer seta) ornamented with fine spinules along outer margin and a stout curved seta (inner seta), swollen at base and naked; outer seta about twice longer than inner seta.

P6 (Fig. 10C). Represented by operculum closing off each genital aperture, ornamented with spine and minute spinule (visible under light microscope).

\section{Male.}

Unknown

\section{REMARKS}

The original description of T. denticula by Wi et al. (2011) was based on female specimens from the south of Cheju Island of Korea (the East China Sea). As mentioned by Wi et al. (2011), this species closely resembles T. rufa in the form of the genital double-somite and the relative length of the outer basal seta and exopodal setae on P5, but differs: 1) in the absence of the dorsoposterior projection on the P2-bearing somite, which is present in T. rufa, a species of the conifera-subgroup; and 2) in the length to width ratio of P5 exopod, being 1.5 times longer than wide, whereas the length is 2.8 times longer than wide in T. rufa (Böttger-Schnack 1999).

Specimens of $T$. denticula from the northeastern equatorial Pacific Ocean agree in almost all morphological characters with the original description of the species from Korean waters, based on the figures published by Wi et al. (2011). But they exhibited some variability in the length ratio of the prosome to urosome (including CR), with the Pacific specimens being larger $(1.9: 1)$ than those in the Korean waters $(1.7: 1)$; in the length to width ratio of the genital double-somite, being somewhat more elongate $(1.7: 1)$ than in the Korean waters specimens (1.5:1); in the length ratio of the caudal ramus to anal somite, which is shorter $(0.6: 1)$ in the Pacific specimens, compared to those in the Korean waters (about same length); and in body size, being somewhat smaller $(648-663 \mu \mathrm{m})$ in our study area than in the Korean specimens $(660-710 \mu \mathrm{m})$ (cf. Table 3$)$.

Wi et al. (2011) mentioned that the exopodal spines on the first exopod segment in P3 and P4 of T. denticula are shortest among the species examined. However, in that study the defi- nition of the proportional lengths of the exopodal spines is not sufficiently clear, as it can be misinterpreted where e.g. "[...] the tip of exopodal spine is reaching [...]". In order to provide more precise information, we calculated the length of the spine on exp-1 relative to the spine on exp- 2 of P3 and P4 in T. denticula from the Korean waters (paratype) in NIBR and from the Pacific Ocean. We also measured the lengths of the endopodal spines on P2-P4 in specimens of the two areas. The resulting length ratios are given in Table 3 . The recalculated ratio values for Korean specimens are largely overlapping with the range of values reported for specimens from the equatorial Pacific Ocean; only the ratio values for spines on P2 enp-3 are not completely overlapping and are tentatively higher for Korean specimens than for the open Pacific specimens.

T. denticula from the Korean waters described by Wi et al. (2011) exhibited numerous small scales on the surfaces of the genital double-somite, the anal somite and the caudal ramus, which were discerned by a using scanning electron microscope. Actually, these structures are hardly discernible with a light microscope due to their small size. In the Pacific specimens, the surface ornamentation of the genital double-somite was probably not fully discerned, but just on the dorsolateral part at half length of the genital double-somite. Also, T. denticula specimens from the two areas seemed to differ in the position of paired integumental pores on the dorsal surface of the genital double-somite, which are located at approximately $2 / 3$ of distance along genital double-somite from anterior margin in the Pacific specimen and in the same vertical line with the genital apertures (cf. Fig. 9A, C), while in the specimen from the Korean waters they were figured as being situated at about half the distance along the genital double-somite from anterior margin and much closer to the lateral margin of the double-somite (Wi et al. 2011: fig. 3C). However, upon reexamination of the undissected female paratype of $T$. denticula (NIBRIV0000214678) during the present study, it was found that the position of paired integumental pores was similar to their position in the Pacific specimens.

The type material of $T$. denticula from the Korean waters which was loaned from the collections of NIBR and reexamined by the senior author of the present study turned out to be insufficient for taxonomic comparisons due to the following reasons:

1) The holotype sample (NIBRIV0000214676) nominated as: "Holotype female dissected and mounted on 1 glass slide" (Wi et al. 2011: 590) was found to contain an undissected female specimen of the dentipes-subgroup of Triconia on this slide.

2) The first paratype sample (NIBRIV0000214677) nominated as: " 2 females dissected and mounted on 3 slides", was in very poor condition and it was difficult to make out the contents on the slides. Recognizable contents were present in only one of the three slides.

3) The second paratype sample (NIBRIV0000214678) nominated as: "[...] 2 undissected females in 1 vial [...]" (Wi et al. 2011: 590) included one female of T. denticula and one female of a species of the dentipes-subgroup of Triconia.

In conclusion, a fundamental revision of the type material of $T$. denticula is required. 
A

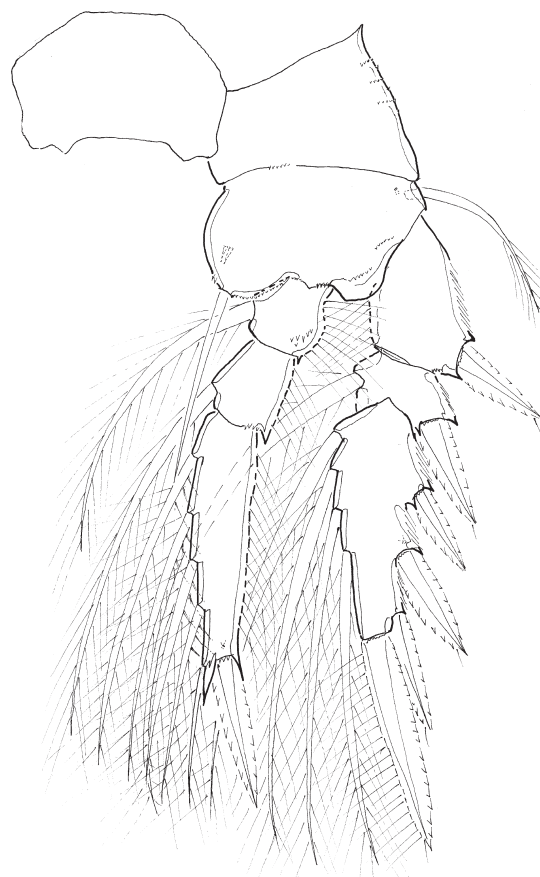

C

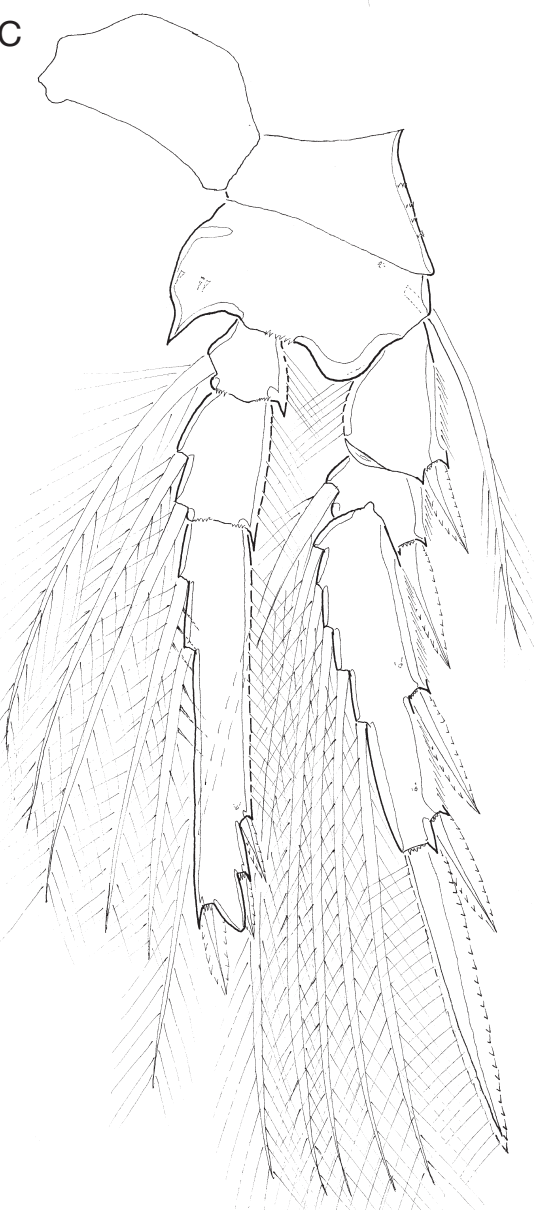

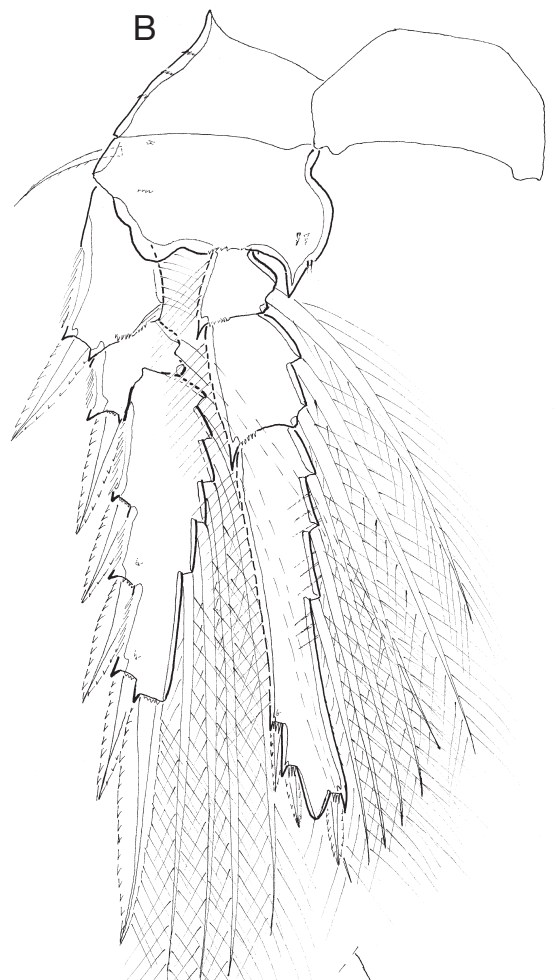

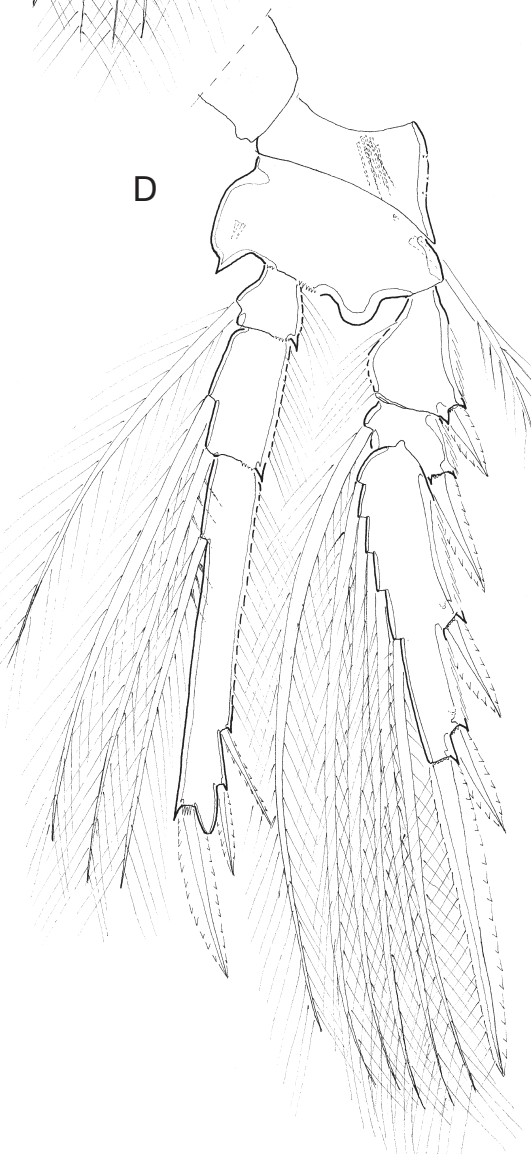

FIG. 12. - Triconia denticula Wi, Shin \& Soh, 2011, female: A, P1, anterior; B, P2, anterior; C, P3, anterior; D, P4, anterior. Abbreviations: see Material and methods. Scale bar: $50 \mu \mathrm{m}$. 


\section{DISCUSSION}

The identification of the species of the Triconia similis-subgroup is difficult, because they look very similar in their morphological characteristics, especially in males. Females of each species can be distinguished mainly by distinct differences in 1) the form of the genital double-somite; 2 ) the length ratio and ornamentation of the exopodal setae and the outer basal seta on P5; and 3) the proportional lengths of the endopodal spines on P2-P4 (Table 3). However, males of the similissubgroup have very similar morphological characteristics such as the form of the genital somite, and the length ratio of the exopodal setae on P5. Thus, to clearly identify males of the Triconia similis-subgroup a combination of several morphological characters mentioned below might be helpful.

Within males of the similis-subgroup, two groups can be distinguished according to the number and position of pores on the dorsal surface of the genital somite: some species have three pores, while others have five pores (Table 4). But integumental structures such as pores are difficult to discern especially under a light microscope. Slight differences among males of the similis-subgroup are also found in the length to width ratio of the caudal ramus, in the proportional lengths of caudal seta VI, and in the proportional length of the exopodal setae on P5 as shown in Table 3. The proportional lengths of the endopodal spines on P2-P4, used to distinguish males by Böttger-Schnack (2004), show some sex-specific differences (Table 2), which had not been taken into account in earlier studies. In the present study, the first information about the intraspecific variability of these ratios for both sexes of species of the similis-subgroup of Triconia is provided, indicating that the measured values of individual spine lengths on the endopods of P2-P4 often fall within a similar range and can be confused between species (Table 3). Therefore care has to be taken when using merely those characters for identification of males.

The length of exopodal spines on $\mathrm{P} 3$ and $\mathrm{P} 4$ might be another morphometric tool to distinguish species, specifically males. The position and length of exopodal spines on the second exopod segment was used to distinguish species of the 2nd group (minuta-subgroup, Cho et al. 2017a) within the similissubgroup of Triconia as well as within the conifera-subgroup (Heron \& Bradford-Grieve 1995). In the present account, we calculated the spine lengths on the exopodal segments 1 and 2 on P3 and P4 for both sexes of the species of the Triconia similis-subgroup from the equatorial Pacific Ocean (Tables 3, 4). The ratio ranges in males of T. komo n. sp. and T. onnuri $\mathrm{n}$. sp. are in the range of variation determined in females respectively. In future, it will be necessary to study the length ratio of the exopodal spines for both sexes of the other four species of the similis-subgroup, including the hitherto unknown male of $T$. denticula.

The males of T. komon. sp. and T. onnuri n. sp. have a paired row of midventral minute denticles or spinous processes at the posterior margin of the P5-bearing somite, which is not found in their respective females. Such characters have not been observed in other species of Triconia so far, but had been reported for other oncaeid species from the study area, such as Oncaea parabathyalis Böttger-Schnack, 2005, O. prolata Heron, 1977, O. tregoubovi Shmeleva, 1968 and Spinoncaea ivlevi (Shmeleva, 1966), where they occur in both sexes (Cho 2011). In the case of Monothula subtilis (Giesbrecht, 1893 ["1892"]), however, the male shows a paired row of denticle processes at the posterolateral margin of the $\mathrm{P} 5$-bearing somite, which is not found in the female (Böttger-Schnack \& Huys 2001; Cho \& Kim 2018). The minute denticles or spinous processes in males of $T$. komo n. sp. and T. onnuri n. sp. are smaller than those of other species and are difficult to observe under a light microscope like other surface structures on the exoskeleton.

Integumental pore patches can be found on the posterolateral part of the cephalosome and the P1-bearing somite in the male of T. onnuri n. sp. (Figs 8B; 13C). Such integumental pores on the lateral margins of the prosome in males have been observed in Oncaea media Giesbrecht, 1891 and O. scottodicarloi Heron \& Bradford-Grieve, 1995, and were recorded for first time in males of Triconia by Heron \& Bradford-Grieve (1995) and by Cho (Cho 2011; Cho et al. 2017b). In females of T. onnuri n. sp. also, ornamentation with minute pores or pits anterior to the genital aperture on the genital double-somite was noted, which can be observed only using SEM (inset of Fig. 13B). Such inconspicuous ornamentation has not been mentioned (or were not observed) in other taxonomic descriptions by using a light microscope. However, when using SEM the ornamentation can be found in T. umerus (Wi et al. 2011: fig. 9E) and T. derivata (Heron \& Bradford-Grieve, 1995) after inspection of the original SEM photo of Fig. 9C in Cho et al. (2017b) (resolution of published figure is not sufficient).In earlier publications on the taxonomy of Oncaeidae species, the armature of female $\mathrm{P} 6$ is mainly delineated as a long, easy-to-recognize spine in light microscope. However, Böttger-Schnack (2001) reported that seven species of Oncaea s.str. are armed with a long spine and two small processes on female P6, verified by using SEM observation, but only the long spine and one process were discernible under a light microscope. In addition, Wi et al. (2010) recently reported that the armature of P6 in Triconia conifera (Giesbrecht, 1891) and T. borealis (Sars, 1918) females have a long spine with two and three processes, respectively, under a scanning electron microscope (SEM), which is different from the earlier description using light microscopy, mentioning only a long spine and one process in T. conifera (cf. Böttger-Schnack 1999: fig. 6H) and a long spine in T. borealis (cf. Heron et al. 1984: fig. 9F). Also, in female $T$. derivata the armature and ornamentation of P6 with a long spine and two processes was recently confirmed by using a SEM (cf. Cho et al. 2017b: fig. 9C), and female T. pacifica Cho, Kim, Böttger-Schnack \& Lee, 2013 of the dentipes-subgroup displayed a long spine and only one minute process in the light microscope, while an additional minute process was discerned under SEM (cf. Cho et al. 2013: figs 2C; 13B). Therefore, when comparing published descriptions of armature and ornamentation of female $\mathrm{P} 6$ of oncaeid species, differences in the methods of observation have to be taken 
into account. The same applies for the description of surface structures on the exoskeleton, such as pores, denticles, etc.

Our report on new species of the similis-subgroup of Triconia has added to the number of described species of this group, which now includes six species: T. similis, T. hawii, T. recta, T. denticula, T. komo n. sp. and T. onnuri n. sp. However, the interpretation of (new) sister or sibling species defined by small morphological differences as mentioned above requires confirmation by alternative taxonomic methods, such as molecular genetic analyses. A recent phylogeographic study on the Paracalanus parvus species complex in the Mediterranean and Black Seas, using molecular (COI) compared to morphological data, "indicated that the taxonomic characters traditionally used are not adequate to discriminate between these species" (Kasapidis et al. 2018). On the other hand, for species of the family Oncaeidae in the Mediterranean Sea, integrative taxonomic methods using morphological and molecular genetic (COI, 12S) data (Böttger-Schnack \& Machida 2011) supported the validity of very refined morphological differences between sibling species e.g. of the dentipes-subgroup, T. dentipes (Giesbrecht, 1891) and T. elongata. New considerations regarding the phylogenetic relationships of the genera Oncaea and Triconia within the Oncaeidae using ITS rDNA data were provided by Di Capua et al. (2017). For the new species in our study, further detailed work on molecular genetic data of the sister-pairs T. similis-T. onnuri n. sp. and T. hawii-T. komo n. sp., would be necessary to fully elucidate their taxonomic status and to prove whether or not the morphological data are of sufficient quality for unequivocal species identification. To set the baseline for zoogeographical comparisons, molecular genetic analyses of copepod material from their respective type localities in: 1) the equatorial eastern Pacific; 2) the Norwegian Sea (T. similis); and 3) the Red Sea (T. hawii), are required.

Among the six species of the similis-subgroup, T. similis has so far been reported from all geographical regions in the ocean (Razouls et al. 2017 at http://copepodes.obs-banyuls. fr/en/fichesp.php?sp=2137), but in view of the morphological similarities between species of the similis- and the minutasubgroup of Triconia, most earlier records of $T$. similis from tropical and/or subtropical areas appear to be doubtful or are based on closely related species (cf. Böttger-Schnack 1999: 53). The species seems to have a bipolar distribution rather than being distributed worldwide (Böttger-Schnack 1999); reliable taxonomic descriptions or records are based on copepod material from the Norwegian Sea, a marginal sea in the North Atlantic Ocean (Sars 1918), the Pacific (Heron 1977; Heron \& Frost 2000; Nishibe \& Ikeda 2004; Nishibe et al. 2009), and the Antarctic area (Heron 1977). The main distribution area of the two species $T$. hawii and T. recta are the Red Sea (Böttger-Schnack 1999, 2000), but Di Capua \& Boxshall (2008) recorded T. hawii also from the Gulf of Naples in the Mediterranean Sea, although some uncertainty on the species identity of $T$. hawii in the Gulf was note by the authors (their pp 1411-1412). Nishibe et al. (2009) identified $T$. hawii at an offshore site in southern Japan, and T. recta was recently found in Korean waters, where it co-occurred with T. denticula (unpublished, one female specimen of T. recta was
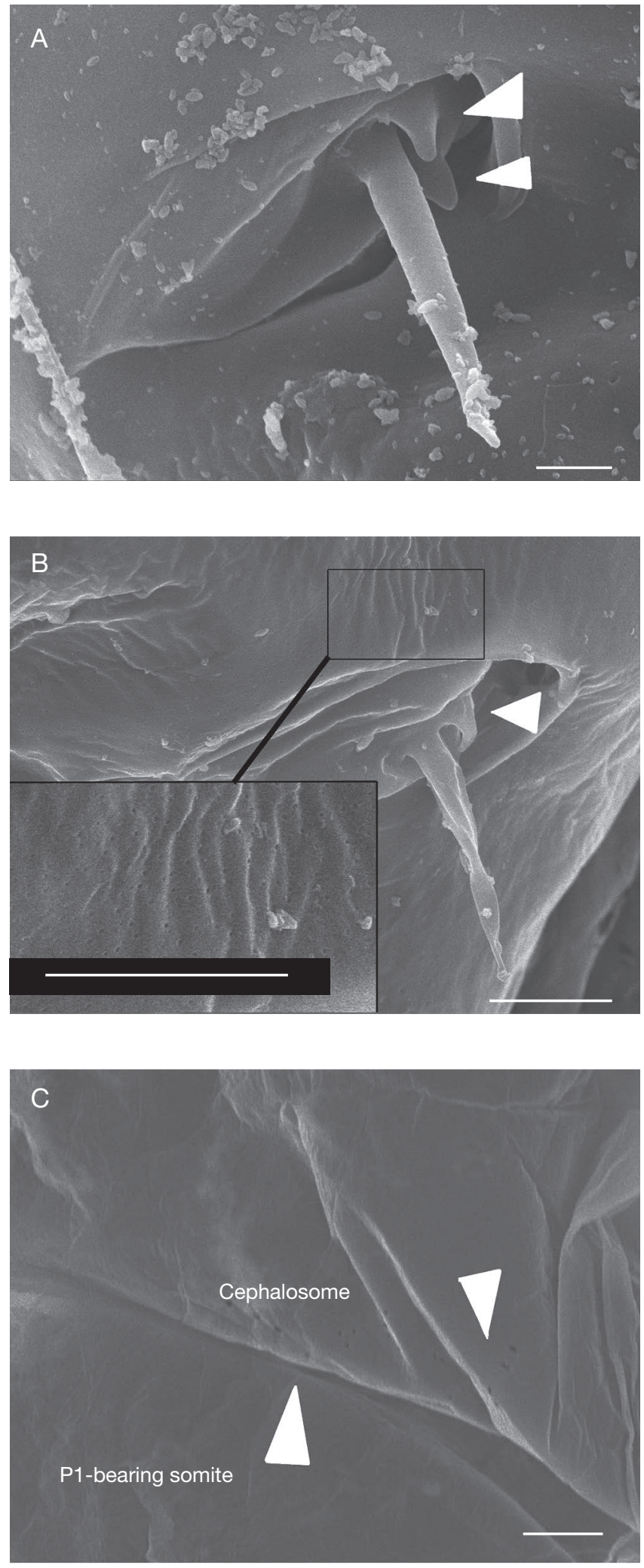

FIG. 13. - A, Triconia komo n. sp. female: genital aperture, arrows indicating two spinous processes; B, Triconia onnuri n. sp. female genital aperture, arrow indicating spinous process, inset showing ornamentation with minute pores or pits above P6; C, male cephalosome, lateral, arrows indicating integumental pores. Scale bars: A, $2 \mu \mathrm{m}$; B, $5 \mu \mathrm{m} ; \mathrm{C}, 10 \mu \mathrm{m}$. 
received from the personal collection of J. H. Wi and identified as $T$. recta by the senior author). Triconia denticula, which so far had been recorded only from the type locality in the Korean waters (Wi et al. 2011) was found in the northeastern tropical Pacific Ocean during the present study. In summary, it can be stated that several species of the similis-subgroup are likely to have a fairly wide distribution range.

In our study area, no information is available on the numerical abundance of small copepod species such as those of the Triconia similis-subgroup, so quantitative comparisons cannot be given. However, among the oncaeid copepods collected for our taxonomic study in the tropical Pacific Ocean, T. komo n. sp. and T. onnuri n. sp. were common species, while $T$. denticula was very rare (four individuals only). It ought to be noted that the occurrence of Triconia species in our samples may not reflect their actual abundance in the area, because only the upper $100 \mathrm{~m}$ of the water column was sampled. Many Triconia species are known to live at greater depths (e.g. Heron \& Bradford-Grieve 1995; Nishibe \& Ikeda 2004; Nishibe et al. 2009; McKinnon et al. 2013) and their occurrence in our epipelagic material may only reflect the "tip of the iceberg".

\section{Acknowledgements}

We wish to thank an anonymous referee and Prof. Geoffey A. Boxshall for critically reading and commenting on the manuscript. Thanks are due to the NIBR staff for approving us to use the scanning electron microscope (JEOL JSM6390LV). This study was supported by the KIMST project "20160099”.

\section{Corrective note}

In the article by Böttger-Schnack, 1999 "Taxonomy of Oncaeidae (Copepoda: Poecilostomatoida) from the Red Sea. - I. 11 species of Triconia gen. nov. and a redescription of T. similis (Sars) from Norwegian waters." published in Mitteilungen aus dem Hamburgischen Zoologischen Museum und Institut, Hamburg 96: 37-128, the following corrections should be made: p. 86 , paragraph 11 :

Instead of "Mandible (Fig. 21D), maxillule (Fig. 21E) and maxilla (Fig. 21F)..." it should read "Mandible (Fig. 22D), maxillule (Fig. 22E) and maxilla (Fig. 22F) as for T. similis, with slight differences in ornamentation of 2 dorsal elements on mandible (Fig. 22D), and 2 allobasal setae on the maxilla (Fig. 22F)."

\section{REFERENCES}

BÖTTGER-SCHNACK R. 1999. - Taxonomy of Oncaeidae (Copepoda, Poecilostomatoida) from the Red Sea. - I. 11 species of Triconia gen. nov. and a redescription of T. similis (Sars) from Norwegian waters. Mitteilungen aus dem Hamburgischen Zoologischen Museum und Institut 96: 37-128.

BÖTTGER-SCHNACK R. 2000. - Taxonomy of Oncaeidae (Copepoda, Poecilostomatoida) from the Red Sea. IV. First record of the male of Triconia recta Böttger-Schnack, with notes on its distribution. Mitteilungen aus dem Hamburgischen Zoologischen Museum und Institut 97: 67-76.

BÖTTGER-SCHNACK R. 2001. - Taxonomy of Oncaeidae (Copepoda: Poecilostomatoida) from the Red Sea. II. Seven species of Oncaea s. str. Bulletin of the Natural History Museum London (Zoology) 67: 25-84.

BÖTTGER-SCHNACK R. 2003. - Taxonomy of Oncaeidae (Copepoda, Poecilostomatoida) from the Red Sea. V. Three species of Spinoncaea gen. nov. (ivlevi-group), with notes on zoogeographical distribution. Zoological Journal of the Linnean Society 137: 187-226. https://doi.org/10.1046/j.1096-3642.2003.00056.x

BÖTTGER-SCHNACK R. 2004. - Triconia parasimilis Böttger-Schnack, 1999 (Copepoda, Oncaeidae), first record from the NW Pacific (Oyashio), with the description of the male. Mitteilungen aus dem Hamburgischen Zoologischen Museum und Institut 101: 213-223.

BÖTTGER-SCHNACK R. 2009. - Taxonomy of Oncaeidae (Copepoda, Cyclopoida s.l.) from the Red Sea. IX. Epicalymma bulbosa n. sp., first record of the genus in the Red Sea. Journal of Plankton Research 31: 1027-1043. https://doi.org/10.1093/plankt/fbp051

BÖTTGER-SCHNACK R. \& BOXSHALl G. A. 1990. - Two new Oncaea species (Copepoda: Poecilostomatoida) from the Red Sea. Journal of Plankton Research 12: 861-871. https://doi.org/10.1093/ plankt/12.4.861

BÖTTGER-SCHNACK R. \& HUYS R. 1998. — Species groups within the genus Oncaea Philippi, 1843 (Copepoda, Poecilostomatoida). Journal of Marine Systems 15: 369-371. https://doi.org/10.1016/ S0924-7963(97)00072-9

BÖTTGER-SCHNACK R. \& HUYS R. 2001. - Taxonomy of Oncaeidae (Copepoda, Poecilostomatoida) from the Red Sea. III. Morphology and phylogenetic position of Oncaea subtilis Gesbrecht, 1892. Hydrobiologia 453/454: 465-481.

BÖTTGER-SCHNACK R. \& MACHIDA R. J. 2011. - Comparison of morphological and molecular traits for species identification and taxonomic grouping of oncaeid copepods. Hydrobiologia 666: 111-125. https://doi.org/10.1007/s10750-010-0094-1

BoXshall G. A. \& HalseY S. H. 2004. - An introduction to copepod diversity. The Ray Society, London, 966 p.

CHO K. 2011. - Study on the taxonomy offamily Oncaeidae (Copepoda, Cyclopoida) from the CCFZ (Clarion-Clipperton Fracture Zone; $C$-C zone) in the Northeast Equatorial Pacific. PhD thesis, Hanyang University, Seoul, $274 \mathrm{p}$.

Cho K., BÖtTGer-Schnack R., Kim W. -S. \& LeE W. 2017b. Two species of the conifera-subgroup of Triconia (Copepoda, Oncaeidae) from the northeastern equatorial Pacific, with a description of the unknown male of T. hirsuta. Zootaxa 4286: 347-369. https://doi.org/10.11646/zootaxa.4286.3.3

CHO K. \& KIM W.-S. 2018. - The first record of Monothula subtilis (Giesbrecht, 1893 ["1892"]) (Cyclopoida, Oncaeidae) in the equatorial Pacific Ocean. Ocean and Polar Research 40: 23-35.

Cho K., Kim W. -S., Böttger-Schnack R. \& LeE W. 2013. A new species of the dentipes-subgroup of Triconia and a redescription of T. giesbrechti and T. elongata (Copepoda: Cyclopoida: Oncaeidae) from the tropical Pacific and the Korea Strait. Journal of Natural History 47: 1707-1743. https://doi.org/10.1080/002 22933.2013.771757

Cho K., Kim W. -S. \& LeE W. 2017a. — Redescription of two species of Triconia (Copepoda, Cyclopoida, Oncaeidae) based on their first records in the tropical Pacific. Korean Journal Environmental Biology 35: 64-82. https://doi.org/10.11626/KJEB.2017.35.1.064

Di CAPUA I. \& Boxshall G. A. 2008. — Records of Oncaeidae (Copepoda) from the Gulf of Naples, with new records of three species of Triconia. Journal of the Marine Biological Association of the United Kingdom 88: 1407-1415. https://doi.org/10.1017/ S002531540800194X

di Capua I., Maffucci F., Pannone R., Mazzocchi M. G., BifFALI E. \& AMATO A. 2017. — Molecular phylogeny of Oncaeidae (Copepoda) using nuclear ribosomal internal transcribed 
spacer (ITS rDNA). PLoS ONE 12 (4):e0175662. https://doi. org/10.1371/journal.pone.0175662

GIESBRECHT W. 1893. — Systematik und Faunistik der pelagischen Copepoden des Golfes von Neapel und der angrenzenden MeeresAbschnitte. Fauna Flora Golf. Neapel 19: 1-831.

Heron G. A. 1977. - Twenty-six species of Oncaeidae (Copepoda: Cyclopoida) from the Southwest Pacific-Antarctic area. Biology of the Antarctic Seas VI. - Antarctic Research Series 26: 37-96.

Heron G. A. \& BradFord-Grieve J. M. 1995. - The marine fauna of New Zealand: Pelagic Copepoda: Poecilostomatoida: Oncaeidae. New Zealand Oceanographic Institute Memoir 104: 1-57.

Heron G. A., English T. S. \& Damkaer D. M. 1984. - Arctic Ocean Copepoda of the genera Lubbockia, Oncaea, and Epicalymma (Poecilostomatoida: Oncaeidae), with remarks on distributions. Journal of Crustacean Biology 4: 448-490. https://doi. org/10.2307/1548043

Heron G. A. \& Frost B. W. 2000. - Copepods of the family Oncaeidae (Crustacea: Poecilostomatoida) in the northeast Pacific Ocean and inland coastal waters of Washington State. Proceedings of the Biological Society of Washington 113: 1015-1063.

Ho J. -S., OHTSUKA S. \& NAKADACHI N. 2006. - A new family of poecilostomatoid copepods (Umazuracolidae) based on specimens parasitic on the black scraper (Thamnaconus modestus) in Japan. Zoological Science 23: 483-496. https://doi.org/10.2108/zsj.23.483

HolthUis L. B. \& VerVOORT W. 2006. — The date of publication of Wilhelm Giesbrecht's "Pelagische Copepoden", in Fauna und Flora des Golfes von Neapel, Vol. 19. Crustaceana 79: 371-374. https://doi.org/10.1163/156854006776759581

Huys R., Gee J. M., Moore C. G. \& Hamond R. 1996. - Synopses of the British Fauna (New Series) No. 51. Marine and brackish water harpacticoid copepods, Part 1. Field Studies Council, Shrewsbury, $352 \mathrm{p}$.

Kasapidis P., Siokou I., Khelifi-Touhami M., Mazzocchi M. G., Matthaiaki M., Christou E., De Puelles M. L. F., Gubanova A., Di Capua I., Batziakas S. \& Frangoulis C. 2018. - Revising the taxonomic status and distribution of the Paracalanus parvus species complex (Copepoda, Calanoida) in the Mediterranean and Black Seas through an integrated analysis of morphology and molecular taxonomy. Journal of Plankton Research 40: 595-605. https://doi.org/10.1093/plankt/fby036

Khodami S., Mcarthur J. V., Blanco-Bercial L. \& MartineZ ARBiZU P. 2017. - Molecular phylogeny and revision of copepod orders (Crustacea: Copepoda). Scientific Reports 7. https:// doi.org/10.1038/s41598-017-06656-4

Khodami S., Mercado-Salas N. F., Tang D. \& Martinez ARBIZU P. 2019. - Molecular evidence for the retention of the
Thaumatopsyllidae in the order Cyclopoida (Copepoda) and establishment of four suborders and two families within the Cyclopoida. Molecular Phylogenetics and Evolution 138: 43-52. https://doi.org/10.1016/j.ympev.2019.05.019

Mckinnon A. D., Duggan S., BÖtTGER-SChnack R., Gusmão L. F. M. \& O'LEARY R. A. 2013. - Depth structuring of pelagic copepod biodiversity in waters adjacent to an Eastern Indian Ocean coral reef. Journal of Natural History 47: 639-665. https:// doi.org/10.1080/00222933.2012.673645

Momaf (Ministry of Maritime AfFairs and Fisheres) 2009. A report on 2008 Deep Sea Bed Mineral Resources Exploration. CRPM 51101-2042-5. MOMAF of Korea, Seoul, 596 p.

Nishibe Y., Hirota Y. \& Ueda H. 2009. - Community structure and vertical distribution of oncaeid copepods in Tosa Bay, southern Japan. Journal of the Marine Biological Association of the United Kingdom 89: 491-498. https://doi.org/10.1017/ S0025315409003087

NisHiBE Y. \& IKEDA T. 2004. - Vertical distribution, abundance and community structure of oncaeid copepods in the Oyashio region, western subarctic Pacific. Marine Biology 145: 931-941. https://doi.org/10.1007/s00227-004-1392-9

Razouls C., De Bovée F., Kouwenberg J. \& Desreumaux N. 2005-2017. - Diversity and Geographic Distribution of Marine Planktonic Copepods. Available at http://copepodes.obs-banyuls. fr/en (Accessed October 07, 2017)

SARS G. O. 1918. - Copepoda Cyclopoida: Lichomolgidae (concluded), Oncaeidae, Corycaeidae, Ergasilidae, Clausiidae, Eunicicolidae, Supplement. An Account of the Crustacea of Norway 6 (13-14): i-xiii, 173-225.

Walter T. C. \& Boxshall G. 2018. - World of Copepods database. Triconia Böttger-Schnack, 1999. Accessed through: World Register of Marine Species at: http://www.marinespecies.org/ aphia.php? $\mathrm{p}=$ taxdetails\&id=128691 on 2018-05-18

Wi J. H., BÖTTGER-SCHNACK R. \& SOH H. Y. 2010. - Species of Triconia of the conifera-subgroup (Copepoda, Oncaeidae) from Korean waters, including a new species. Journal of Crustacean Biology 30: 673-691. https://doi.org/10.1651/10-3301.1

Wi J. H., BÖTTGER-SCHNACK R. \& SOH H. Y. 2012. - Two new species belonging to the dentipes- and conifera-subgroups of Triconia (Copepoda: Cyclopoida: Oncaeidae) from the East China Sea. Journal of Crustacean Biology 32: 843-859. https:// doi.org/10.1163/193724012X650659

WI J. H., SHIN K. S. \& SoH H. Y. 2011. - The similis-subgroup within Triconia (Copepoda: Cyclopoida: Oncaeidae) from Korean waters (East China Sea), including a new species. Zoological Studies 50: 588-604. 